\title{
Lighting up NIR-II Fluorescence In Vivo: An Activable Probe for Non-invasive Hydroxyl Radical Imaging
}

Wenqi Feng, Yuying Zhang, Zhen Li, Shuyang Zhai, Weijie Lv and Zhihong Liu*

Key Laboratory of Analytical Chemistry for Biology and Medicine (Ministry of

Education), College of Chemistry and Molecular Sciences, Wuhan University, Wuhan 430072, China

Email: zhhliu@whu.edu.cn 


\section{Table of Contents}

(page)

(S-3) Materials and apparatus.

(S-3) Measurement of fluorescence quantum yield.

(S-4) Theoretical calculation.

(S-4) Cell culture, cytotoxicity test and confocal fluorescence imaging.

(S-4) LC-MS sample preparation.

(S-5) Scheme S1. Synthesis route of Et-1080 and Hydro-1080.

(S-6) Table S1-S2. Photophysical properties of Et-1080 and Hydro-1080 in different solvents.

(S-7-S-11) Figure S1-S9. Spectroscopic properties of Et-1080 and Hydro-1080.

(S-12) Figure S10. High resolution mass spectrum of the reaction product of Hydro1080 and $1 \mu \mathrm{M} \cdot \mathrm{OH}$.

(S-12) Figure S11. Viability of HeLa cells incubated with different concentrations of Hydro-1080 for 24 hours.

(S-13) Figure S12. Absorption spectrum and the photograph of Hydro-1080 injection $(1 \mathrm{mM})$.

(S-13) Figure S13. Confocal fluorescence images of RAW 264.7 macrophage cells.

(S-14) Figure S14. Typical chromatogram of 2,3-DHBA and 2,5-DHBA in MRM mode.

(S-14) Figure S15. Quantitive analysis of 2,3-DHBA in mice liver (LPS model).

(S-15) Figure S16. Confocal fluorescence images of HepG2 cells.

(S-15) Figure S17. Quantitive analysis of 2,3-DHBA in mice liver (APAP model).

(S-16) Figure S18. NIR-IIa fluorescence image of organs and tissues of Figure 6a/e group mice.

(S-17-S-24) Figure S19-S30. ${ }^{1} \mathrm{H}$ NMR, ${ }^{13} \mathrm{C}$ NMR and mass spectra of products.

(S-24) References 


\section{Materials and apparatus.}

IR-1061, Tween 80, lipopolysaccharide (LPS), 2,3-dihydroxybenzoic acid (2,3DHBA), 2,5-DHBA were purchased from Sigma-Aldrich. Acetaminophen (APAP), 3(4,5-dimethylthiazol-2-yl)-2,5-diphenyltetrazolium bromide (MTT), sodium salicylate were purchased from Aladdin Reagent Co., Ltd (Shanghai, China). 1Aminobenzotriazole (ABT) was purchased from Bidepharm Co., Ltd (Shanghai, China). Hydroxyphenyl fluoresce (HPF) was purchased from AAT Bioquest, Inc. Other reagents were purchased from commercial suppliers and used without further purification. Mass spectrometry was performed on Ultimate3000\&Compact (Bruker, Germany), LTQ Orbitrap Elite (Thermo Fisher Scientific, America) and Biotech Axima TOF2 (Shimadzu, Japan) mass spectrometers. LC-MS analysis was performed on a LCMS-8045 (Shimadzu, Japan) instrument with a Shimadzu C18 column $(100 \times 2.1 \mathrm{~mm}$, $3 \mu \mathrm{m})$. Absorption spectra were recorded on a UV-vis-NIR spectrophotometer (Shimadzu UV-3600, Japan). NIR-II fluorescence spectra were excited by a 980-nm laser (Beijing Hi-Tech Optoelectronic Co., Ltd.) and recorded with a fluorometer (Fluorolog-3, Horiba Jobin Yvon, France). Confocal fluorescence imaging was was performed on a PerkinElmer UltraVIEW VoX microscope.

\section{Measurement of fluorescence quantum yield $(\Phi)$.}

NIR-II fluorescence quantum yield was measured according to the literature. ${ }^{1}$ As reported quantum yield of IR-26 is inconsistent, IR-1061 was chosen as the reference $\left(\Phi=1.7 \%\right.$ in dichloromethane). ${ }^{2,3}$ In briefly, 5 samples with different absorbance $(\sim 0.02,0.04,0.06,0.08$ and 0.1$)$ at $980 \mathrm{~nm}$ were prepared. Absorption and integrated fluorescence intensity under 980-nm excitation were measured. Then linear fits of integrated fluorescence intensity to absorbance were performed and slopes were used in equation below to calculate the fluorescence quantum yield:

$$
\Phi_{\text {sample }}=\Phi_{\text {ref }} \cdot \frac{n_{\text {sample }}^{2}}{n_{\text {ref }}^{2}} \cdot \frac{\text { Slope }_{\text {sample }}}{\text { Slope }_{\text {ref }}}
$$


Where sample and ref are for sample and reference (IR-1061 in dichloromethane), $\mathrm{n}$ is for refractive index.

\section{Theoretical calculation.}

Geometries of Et-1080 and Hydro-1080 were optimized at B3LYP/6-31+G(d) level by Gaussian 09 program. ${ }^{4}$ Then HOMOs and LUMOs were calculated at the same level.

\section{Cell culture, cytotoxicity test and confocal fluorescence imaging.}

HeLa, RAW 264.7 and HepG2 cells were cultured in Dulbecco's modified Eagle's medium (DMEM) supplemented with $100 \mathrm{U} / \mathrm{mL}$ penicillin, $100 \mu \mathrm{g} / \mathrm{mL}$ streptomycin and $10 \%$ fetal bovine serum with an atmosphere of $5 \% \mathrm{CO}_{2}$ at $37{ }^{\circ} \mathrm{C}$. HeLa cells were passed and plated into 96-well microplates for cytotoxicity test. Cells were incubated with 0 to $20 \mu \mathrm{M}$ Hydro-1080 in DMEM for $24 \mathrm{~h}$, then incubated $4 \mathrm{~h}$ with MTT (1 $\mathrm{mg} / \mathrm{mL}$ ) except one row. Then medium was replaced by DMSO to dissolve formazan. Then the absorbance at $490 \mathrm{~nm}$ was measured. As Hydro-1080 has obvious absorption at $490 \mathrm{~nm}$, the cell viability was calculated as: Cell viability $=$ (mean absorbance of probe and MTT treated wells - mean absorbance of same concentration probe treated wells)/mean absorbance of control wells $\times 100 \%$. RAW 264.7 and HepG2 cells were transferred into glass-bottomed confocal dishes two days before fluorescence imaging. Fluorescence of HPF was collected with $488 \mathrm{~nm}$ laser excitation and 525/50 bandpass emission filter.

\section{LC-MS sample preparation.}

Mice livers were rapidly dissected, washed with saline and weighted after euthanasia. Livers were homogenized with 5 weights of saline, then the homogenate was centrifuged to obtain supernatant. $200 \mu \mathrm{L}$ of supernatant was mixed with $20 \mu \mathrm{L}$ of $3 \mathrm{M}$ $\mathrm{HCl}$, then the mixture was extracted by a solid phase extraction (SPE) column. A C18 SPE column (200 mg, 3mL) was washed with $2 \mathrm{~mL}$ acetonitrile and activated with 2 
$\mathrm{mL} 0.3 \%$ formic acid, then loaded with sample and washed with $2 \mathrm{~mL} 0.3 \%$ formic acid. Finally, $1 \mathrm{~mL}$ acetonitrile was used for elution. The solution was then kept at $4{ }^{\circ} \mathrm{C}$ until LC-MS analysis. The external standard method was adopted for 2,3-DHBA quantitive analysis.
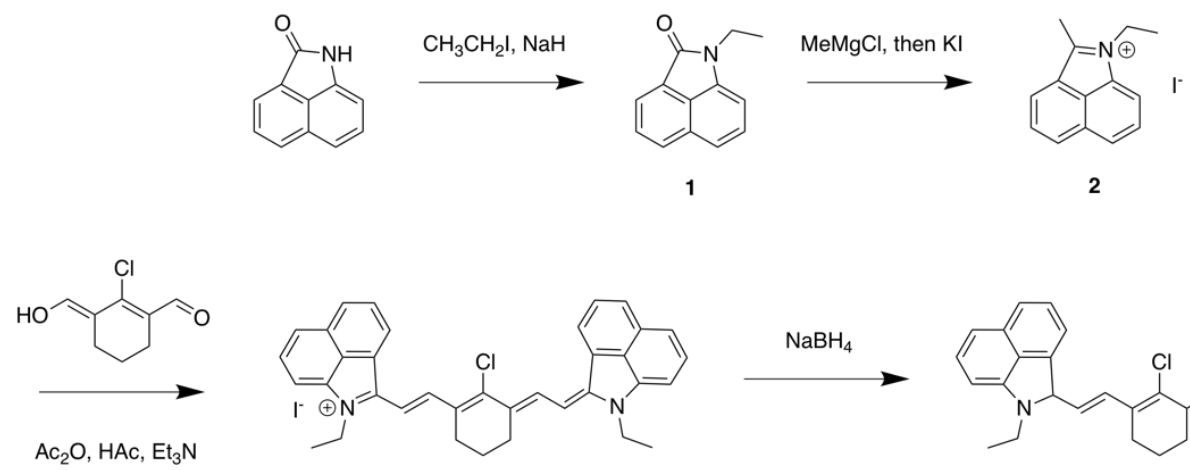

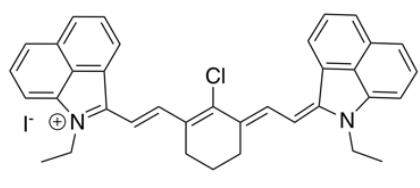

Et-1080

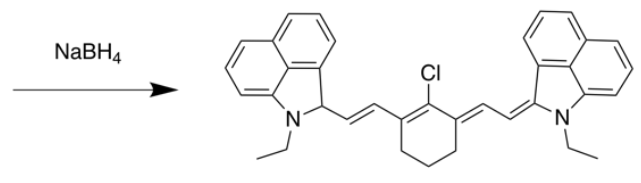

Hydro-1080

Scheme S1. Synthesis route of Et-1080 and Hydro-1080. 
Table S1. Photophysical properties of Et-1080 in different solvents.

\begin{tabular}{lllll}
\hline Solvent & $\lambda_{\text {abs }}(\mathrm{nm})^{[\mathrm{a}]}$ & $\varepsilon_{\max }\left(\mathrm{cm}^{-1} \mathrm{M}^{\left.-1 \cdot 10^{4}\right)^{[\mathrm{b}]}}\right.$ & $\lambda_{\mathrm{em}}(\mathrm{nm})^{[\mathrm{c}]}$ & $\Phi(\%)^{[\mathrm{d}]}$ \\
\hline Dichloromethane & 1025 & 19.16 & 1062 & 0.84 \\
Methanol & 1009 & 16.36 & 1046 & \\
Ethanol & 1016 & 16.27 & 1051 & 0.32 \\
Ethylene glycol & 1025 & 13.91 & 1060 & \\
Acetonitrile & 1012 & 12.74 & 1052 & 0.4 \\
DMSO & 1039 & 11.17 & 1080 & 0.45 \\
DMF/PBS =1/1 & 1021 & 9.37 & 1054 & 0.08 \\
\hline
\end{tabular}

[a] Maximum absorption peak. [b] Molar extinction coefficient. [c] Maximum emission peak. [d] Fluorescence quantum yield.

Table S2. Photophysical properties of Hydro-1080 in different solvents.

\begin{tabular}{llll}
\hline Solvent & $\lambda_{\text {abs }}(\mathrm{nm})$ & $\varepsilon_{\max }\left(\mathrm{cm}^{-1} \mathrm{M}^{-1} \cdot 10^{4}\right)$ & $\lambda_{\mathrm{em}}(\mathrm{nm})^{[\mathrm{e}]}$ \\
\hline Dichloromethane & 523 & 3.76 & 570 \\
Methanol & 517 & 4.07 & 572 \\
Ethanol & 519 & 4.00 & 573 \\
Ethylene glycol & 523 & 2.60 & 570 \\
Acetonitrile & 518 & 3.93 & 572 \\
DMSO & 527 & 3.46 & 576 \\
DMF/PBS = 1/1 & 525 & 2.43 & 598 \\
\hline
\end{tabular}

[e] Fluorescence was collected under $500 \mathrm{~nm}$ excitation. 

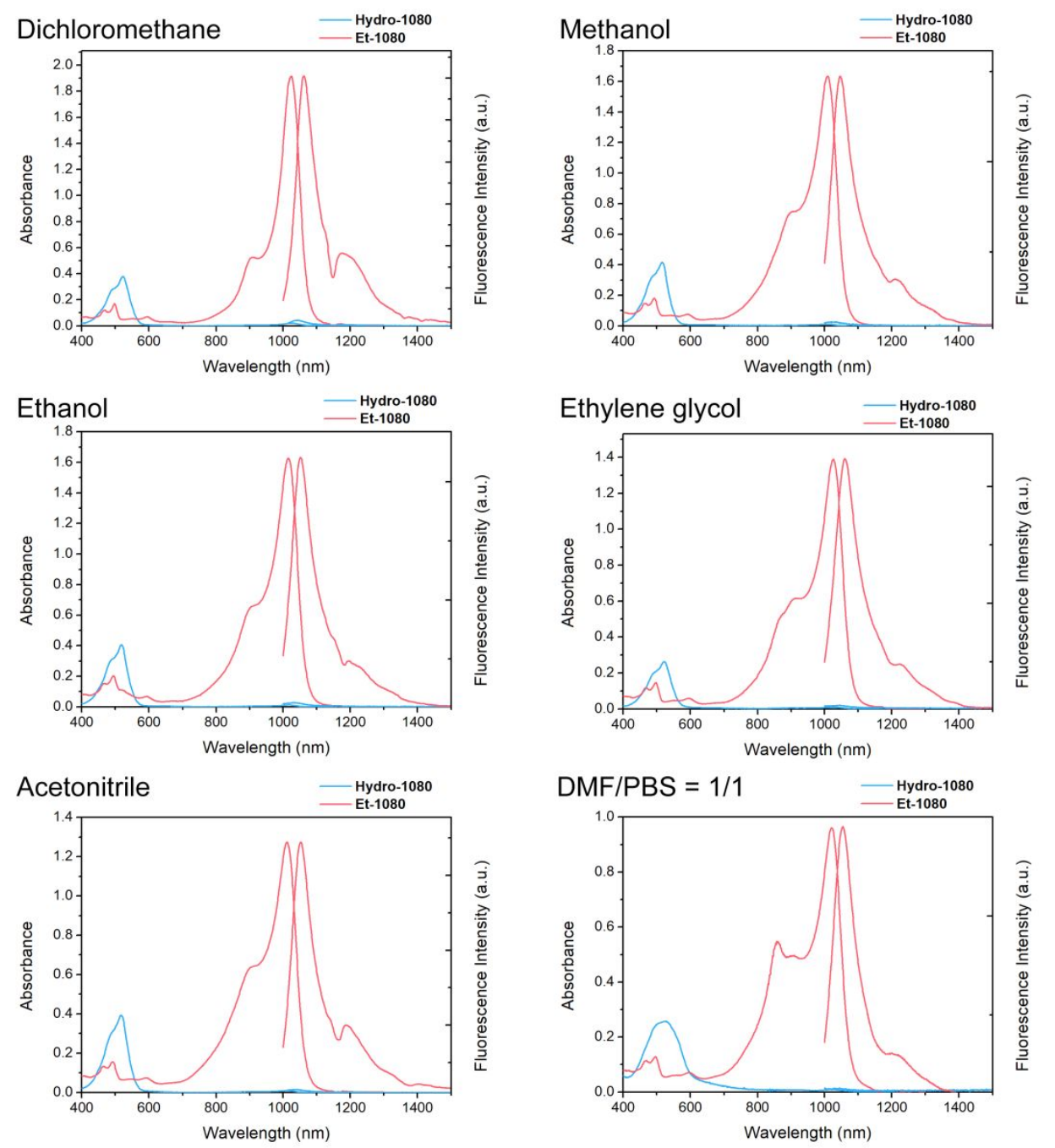

Figure S1. Absorption (left) and fluorescence (right) spectra of Hydro-1080 (blue line) and Et-1080 (red line) $(10 \mu \mathrm{M})$ in various solvents. Please note that fluorescence was collected under 980-nm laser excitation. 


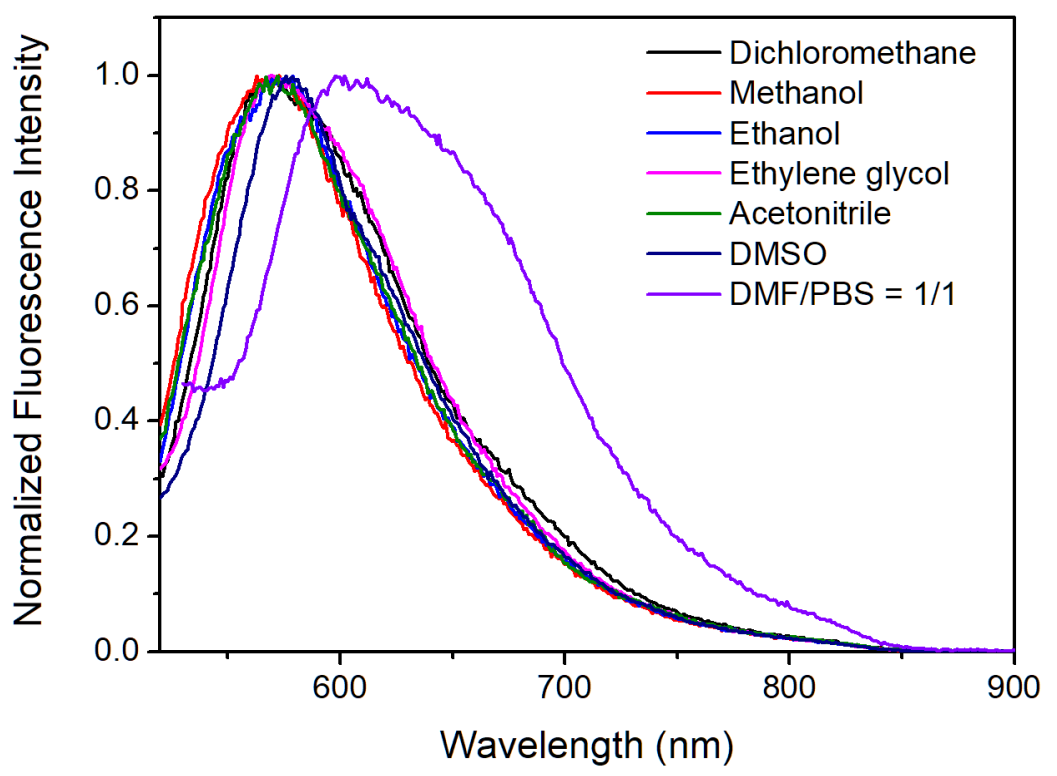

Figure S2. Fluorescence spectra (visible region) of Hydro-1080 $(10 \mu \mathrm{M})$ in various solvents. Please note that fluorescence was collected under 500-nm excitation.

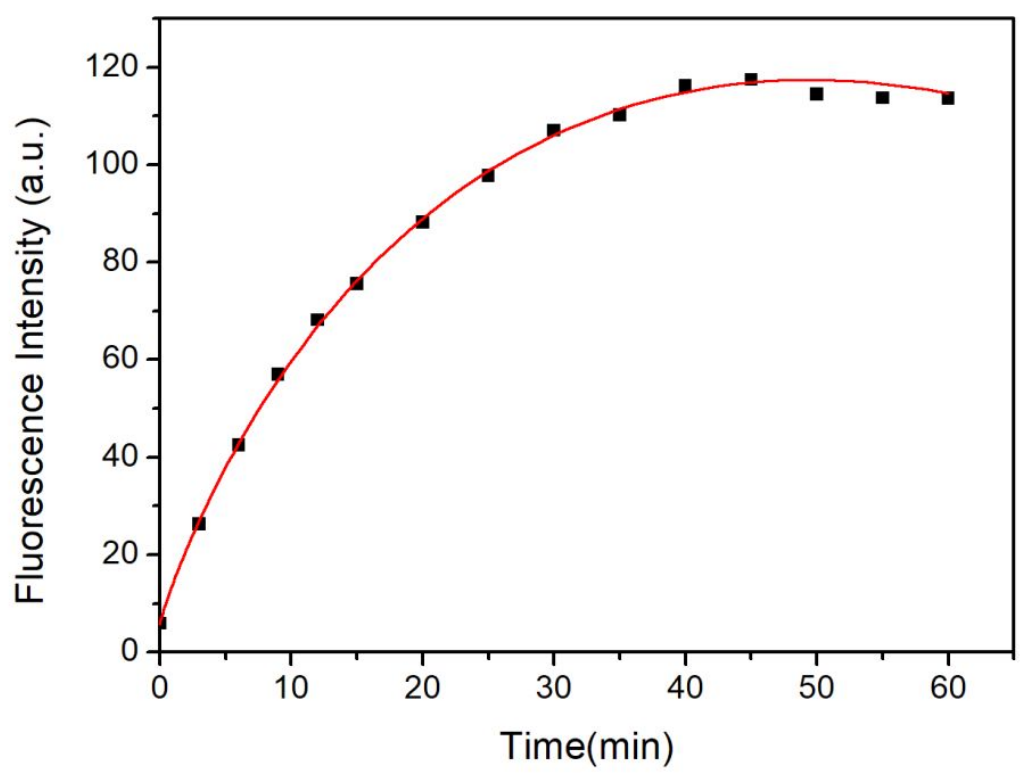

Figure S3. Kinetics curve of Hydro-1080 toward $2 \mu \mathrm{M} \cdot \mathrm{OH}$. 


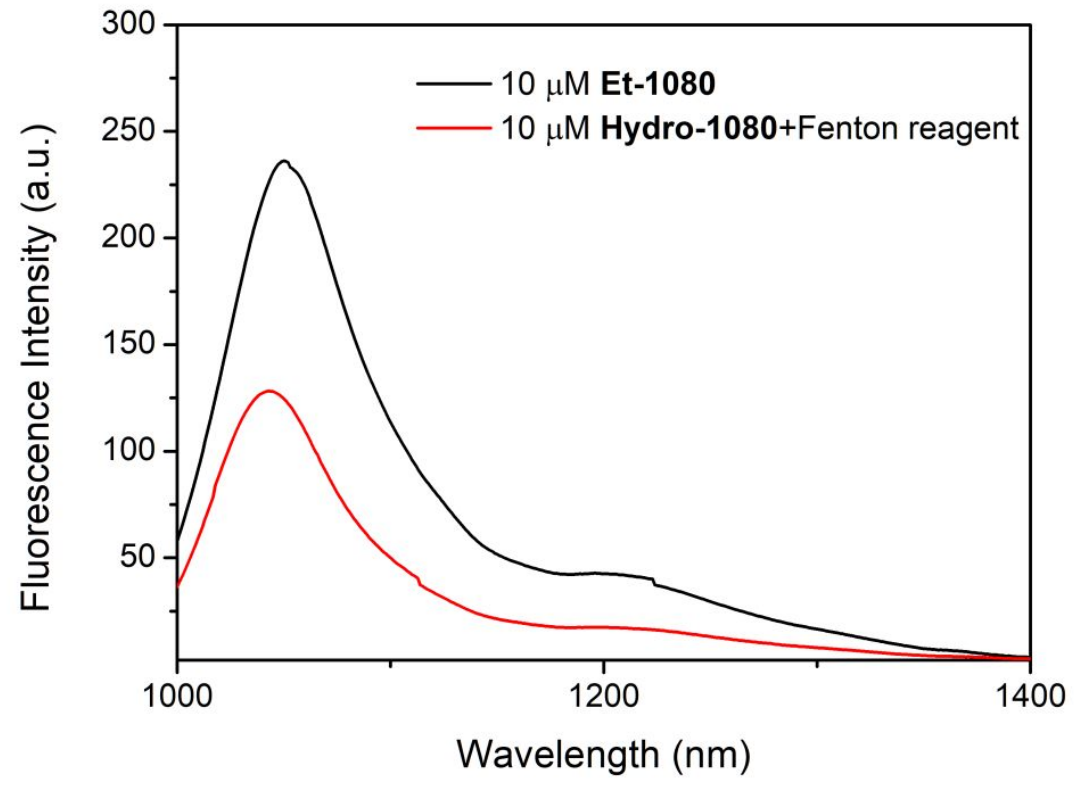

Figure S4. Fluorescence spectra of $10 \mu \mathrm{M}$ Et-1080 (black line) and $10 \mu \mathrm{M}$ Hydro1080 with Fenton reagent (red line) in $0.1 \mathrm{mM} \mathrm{H}_{2} \mathrm{SO}_{4} / \mathrm{DMF}=1 / 1$ mixture. The fluorescent recovery ratio was found to be $56 \%$.

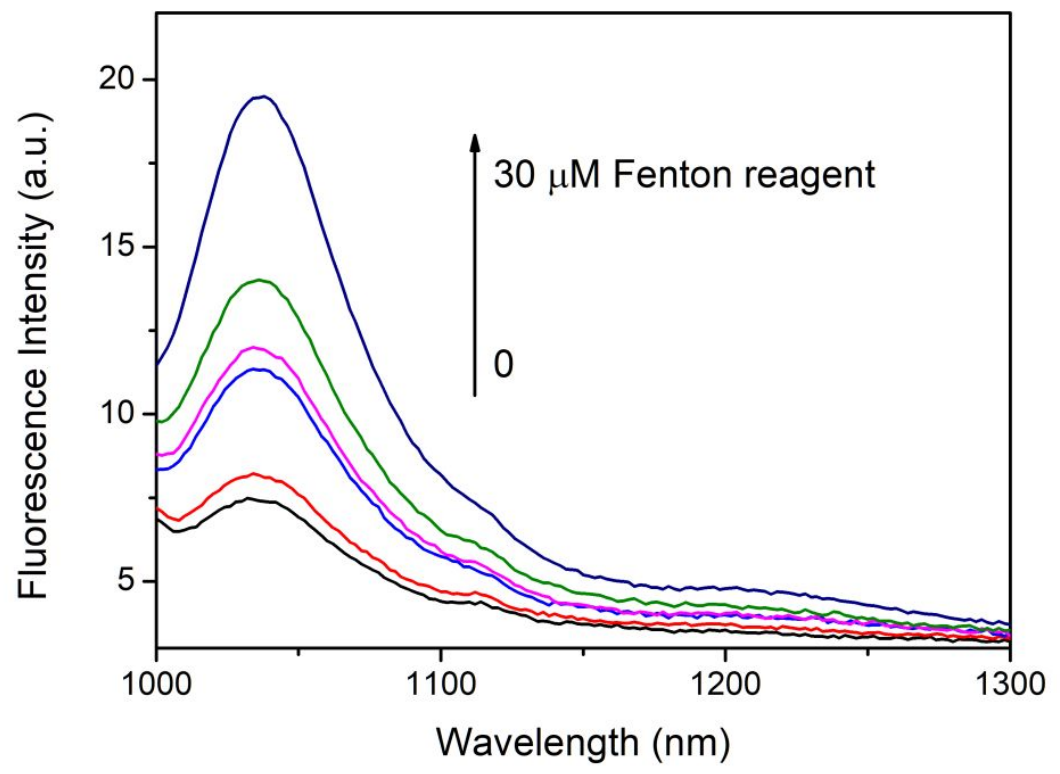

Figure S5. Fluorescence response of Hydro-1080 toward different concentrations of Fenton reagent in $10 \mathrm{mM}$ PBS $(\mathrm{pH}=7.4) / \mathrm{DMF}=1 / 1$ mixture. 


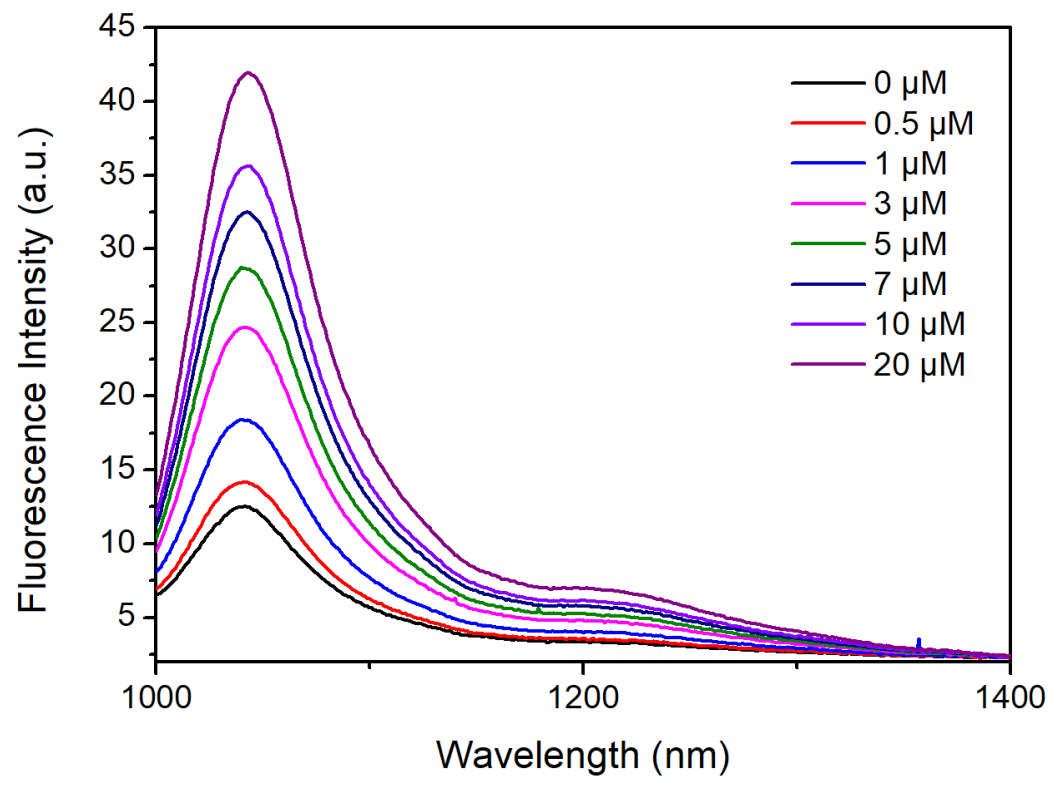

Figure S6. Fluorescence response of Hydro-1080 toward different concentrations of $\mathrm{Fe}^{2+}$-EDTA in $0.1 \mathrm{mM} \mathrm{H}_{2} \mathrm{SO}_{4} / \mathrm{DMF}=1 / 1$ mixture.

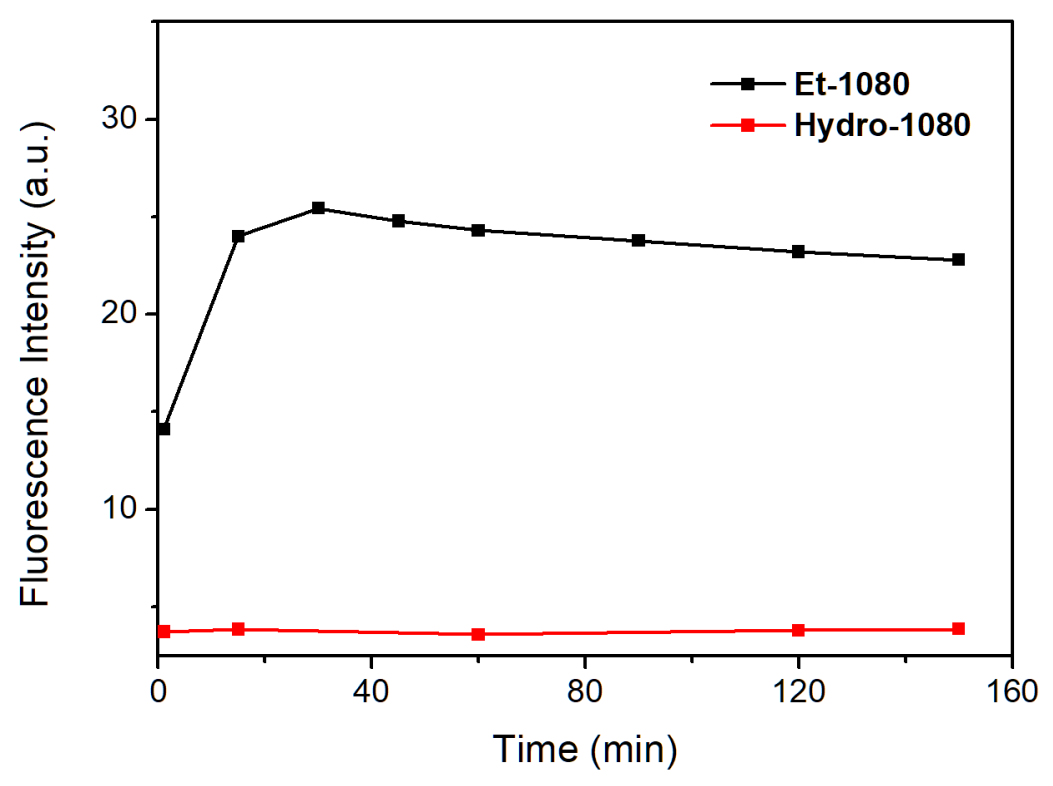

Figure S7. Stability of Hydro-1080 and Et-1080 $(10 \mu \mathrm{M})$ in 20\% FBS solution under $37{ }^{\circ} \mathrm{C}$ incubation. 


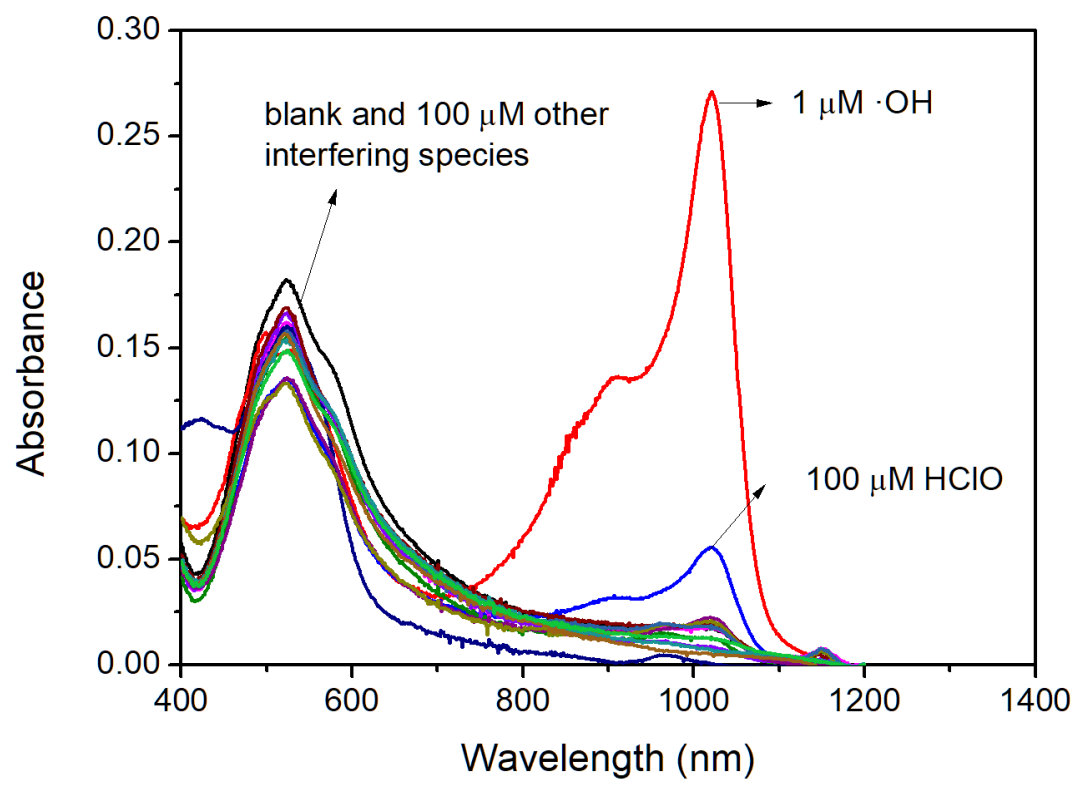

Figure S8. Absorption spectra of Hydro-1080 to various interfering species (100 $\mu \mathrm{M}$ of $\mathrm{ClO}^{-}, \mathrm{ONOO}^{-}, \mathrm{H}_{2} \mathrm{O}_{2}, \mathrm{O}_{2} \cdot{ }^{\cdot-},{ }^{1} \mathrm{O}_{2}, \mathrm{ROO} \cdot$, tBuO$\cdot$, tBuOOH, NO, Cys, Hcy, GSH) and $\cdot \mathrm{OH}$. Interfering species displayed minor response and did not degrade Hydro1080.

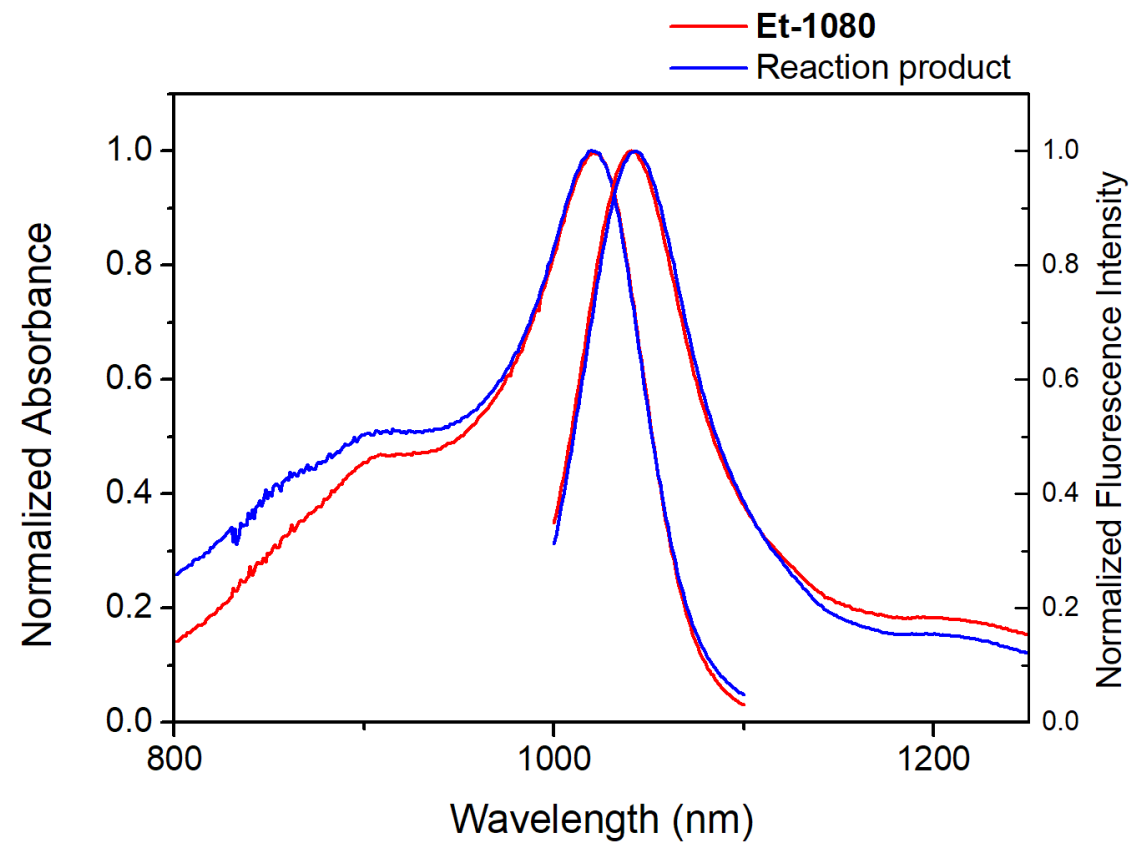

Figure S9. Normalized absorption (left) and fluorescence (right) spectra of $1 \mu \mathrm{M}$ Et1080 (red line) and the reaction product of Hydro-1080 and $1 \mu \mathrm{M} \cdot \mathrm{OH}$ in $0.1 \mathrm{mM}$ $\mathrm{H}_{2} \mathrm{SO}_{4} / \mathrm{DMF}=1 / 1$ mixture. 


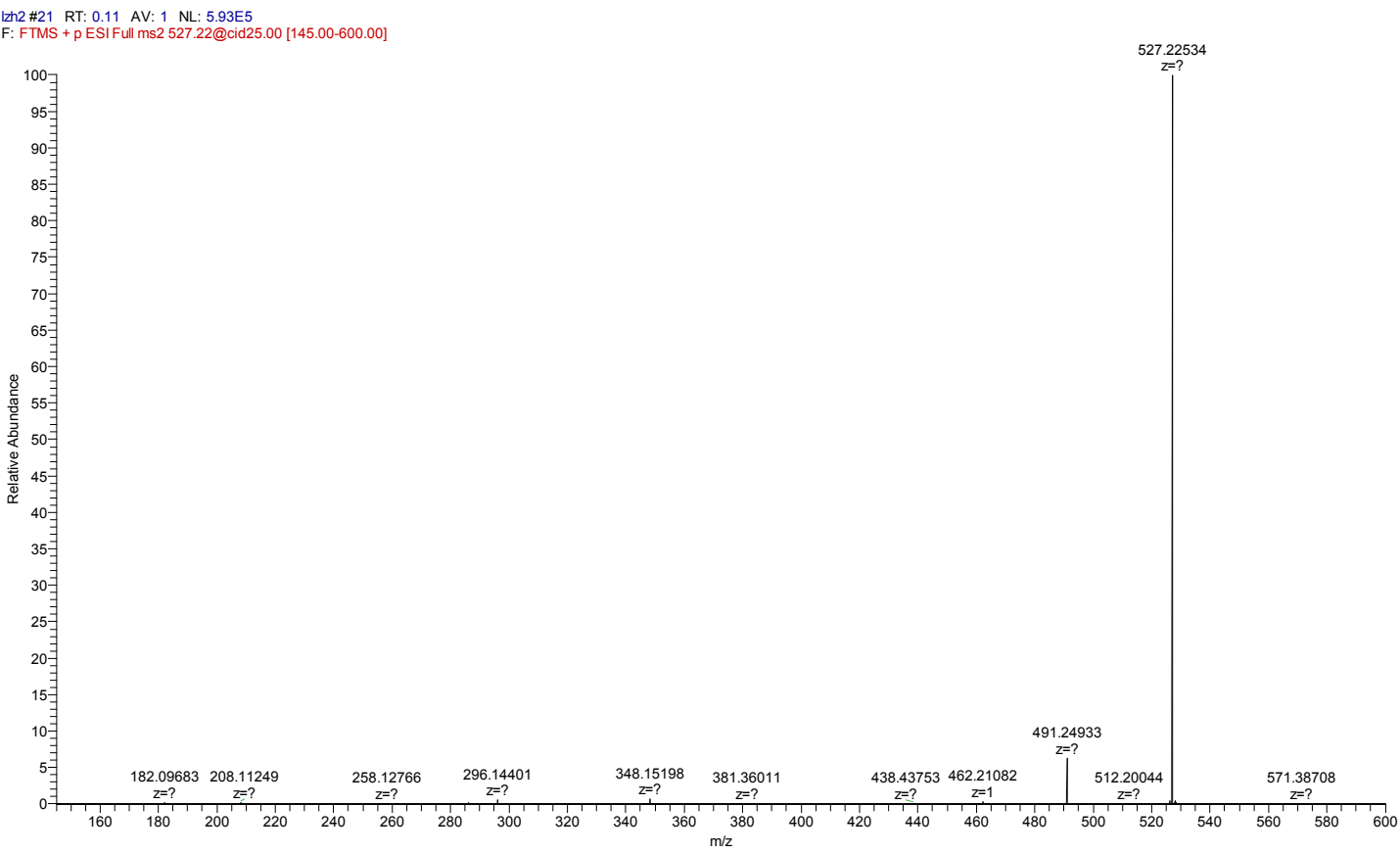

Figure S10. High resolution mass spectrum of the reaction product of Hydro-1080 and $1 \mu \mathrm{M} \cdot \mathrm{OH}$.

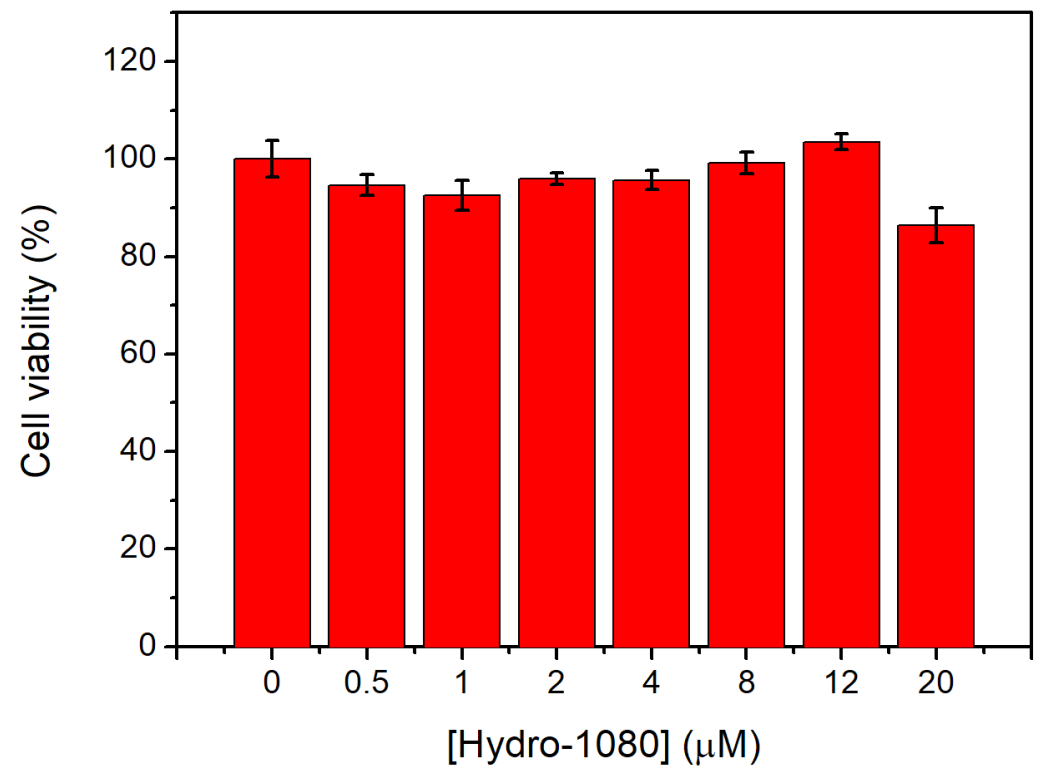

Figure S11. Viability of HeLa cells incubated with different concentrations of Hydro1080 for 24 hours. 


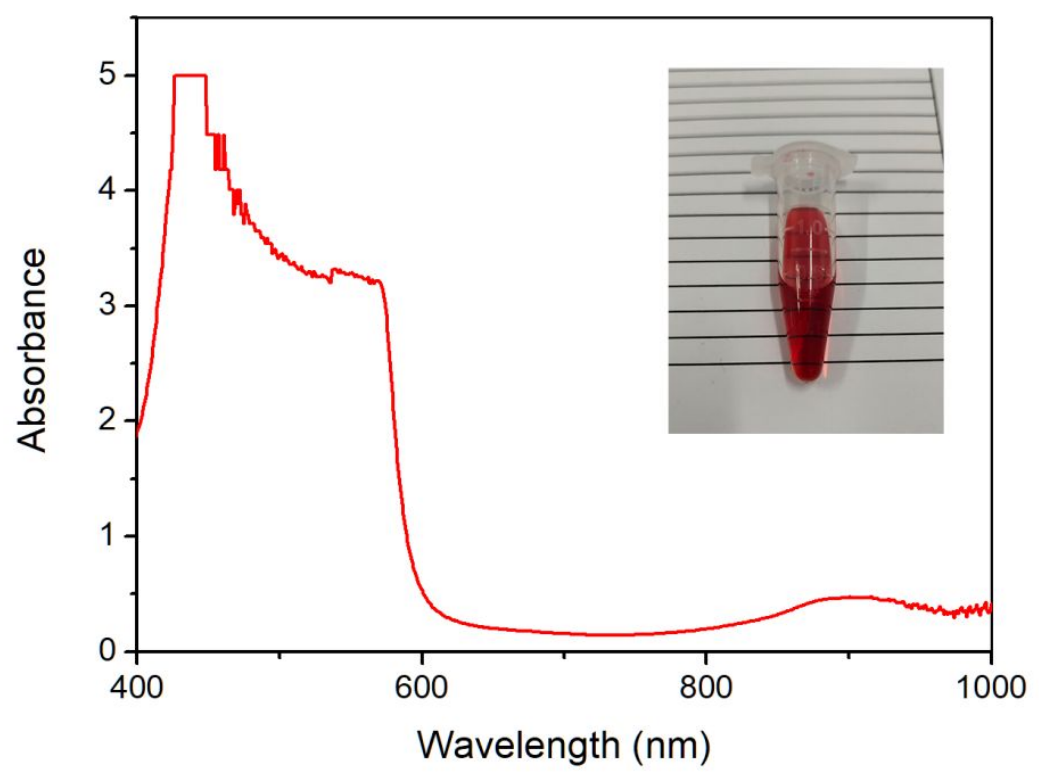

Figure S12. Absorption spectrum of Hydro-1080 injection (1mM). Inset: photograph of the injection.
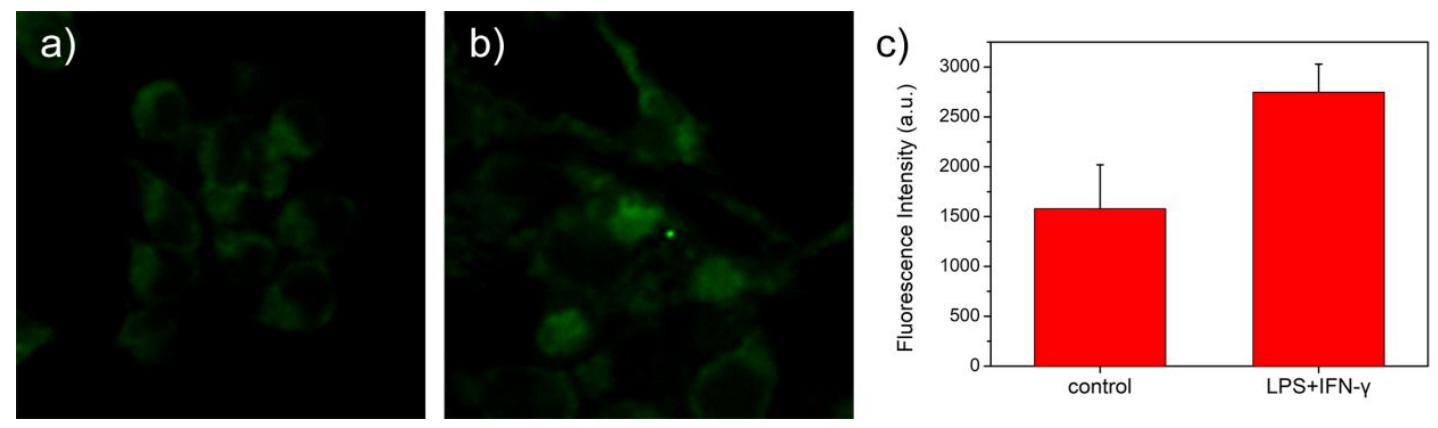

Figure S13. Confocal fluorescence images of RAW 264.7 macrophage cells with (a) blank or (b) $1 \mu \mathrm{g} / \mathrm{mL}$ LPS and $0.1 \mu \mathrm{g} / \mathrm{mL}$ IFN- $\gamma$ for $15 \mathrm{~h}$, then $5 \mu \mathrm{M} \cdot \mathrm{OH}$ probe HPF for 1 h. (c) Fluorescence intensity of a-b group cells. 


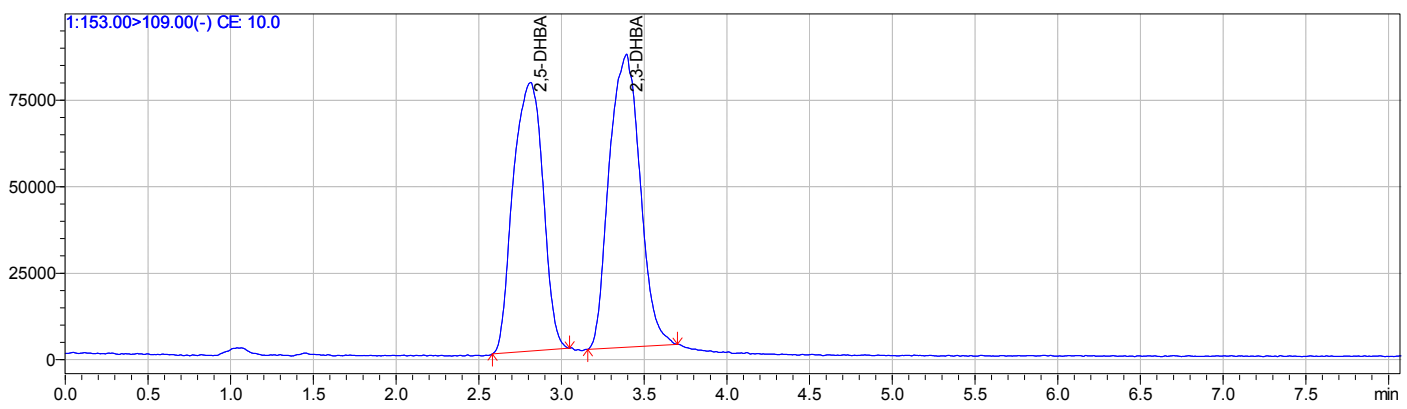

Figure S14. Typical chromatogram of 2,3-DHBA and 2,5-DHBA in MRM mode. A mixture of $0.3 \%$ formic acid in water/acetonitrile was used as the mobile phase (80:20, $\mathrm{v} / \mathrm{v})$ with a flow rate of $0.2 \mathrm{~mL} / \mathrm{min}$. The mass transition was $153>109(\mathrm{~m} / \mathrm{z})$ under negative mode and the collision energy was $10 \mathrm{eV}$. Under this condition, 2,3-DHBA could be completely seperated from 2,5-DHBA.

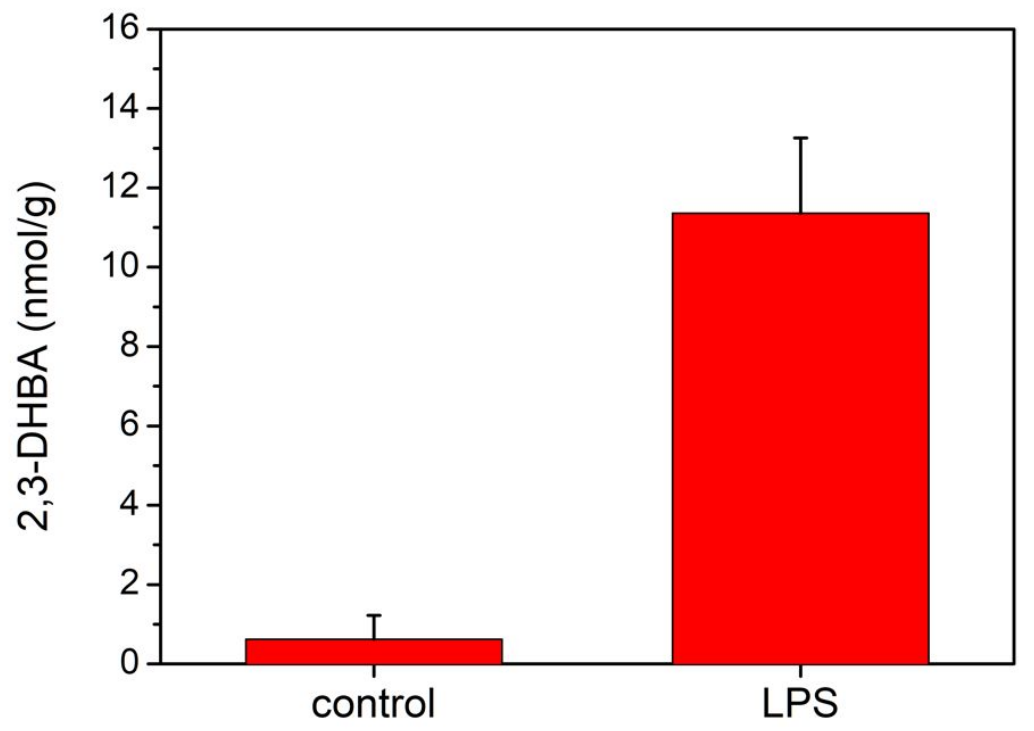

Figure S15. Quantitive analysis of 2,3-DHBA in mice liver (LPS model). Mice were intravenously injected with 0 or $40 \mathrm{mg} / \mathrm{kg}$ LPS for $24 \mathrm{~h}$, then intraperitoneally injected with $100 \mathrm{mg} / \mathrm{kg}$ salicylic acid for $1 \mathrm{~h}$. Then mice livers were harvested and concentrations of 2,3-DHBA were measured by LC-MS. Salicylic acid was used as a $\cdot \mathrm{OH}$ trapper; 2,3-DHBA was the specific product of salicylic acid and $\cdot \mathrm{OH}$. The concentration of 2,3-DHBA reflected $\cdot \mathrm{OH}$ level. 

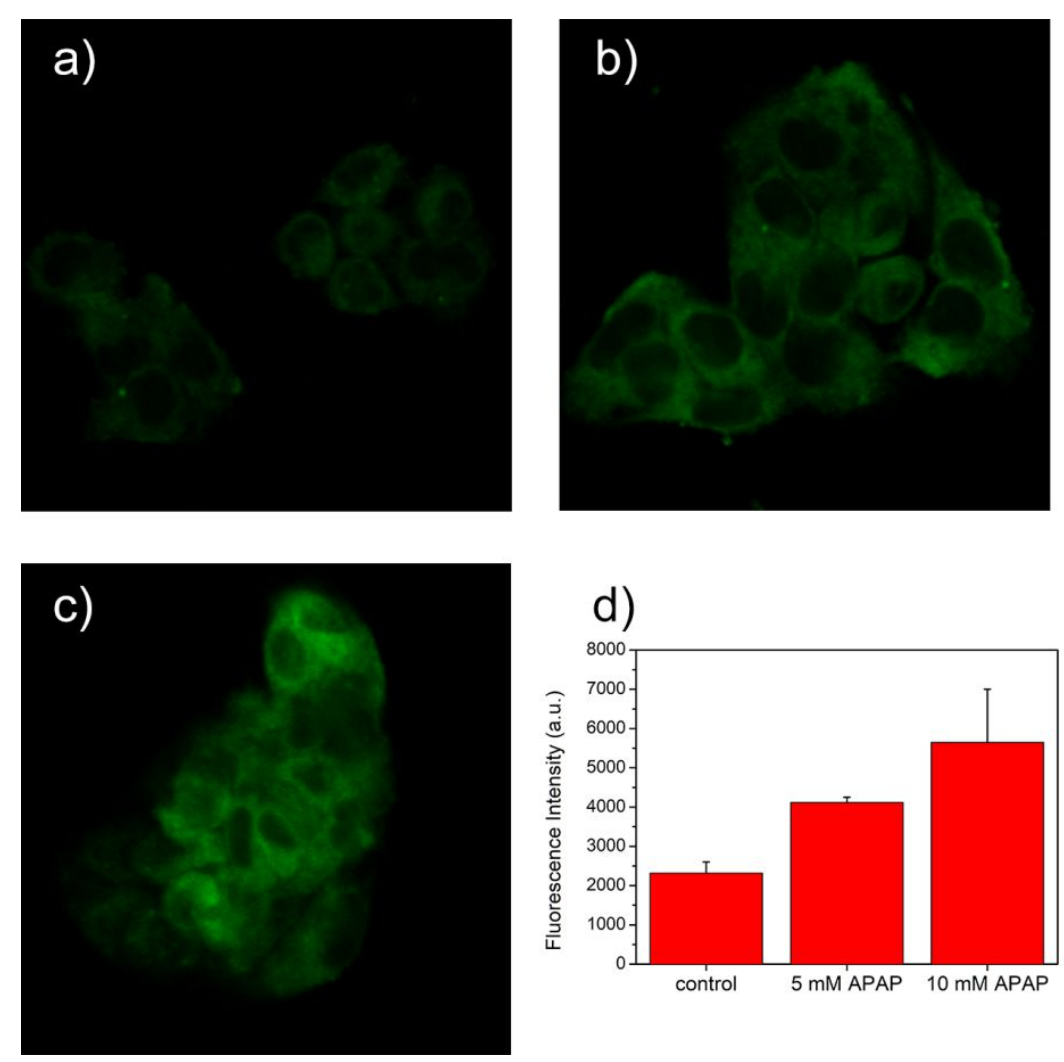

Figure S16. Confocal fluorescence images of HepG2 cells with (a) blank, (b) $5 \mathrm{mM}$ APAP or (c) $10 \mathrm{mM}$ APAP for $24 \mathrm{~h}$, then $5 \mu \mathrm{M} \cdot \mathrm{OH}$ probe HPF for $1 \mathrm{~h}$. (d) Fluorescence intensity of a-c group cells.

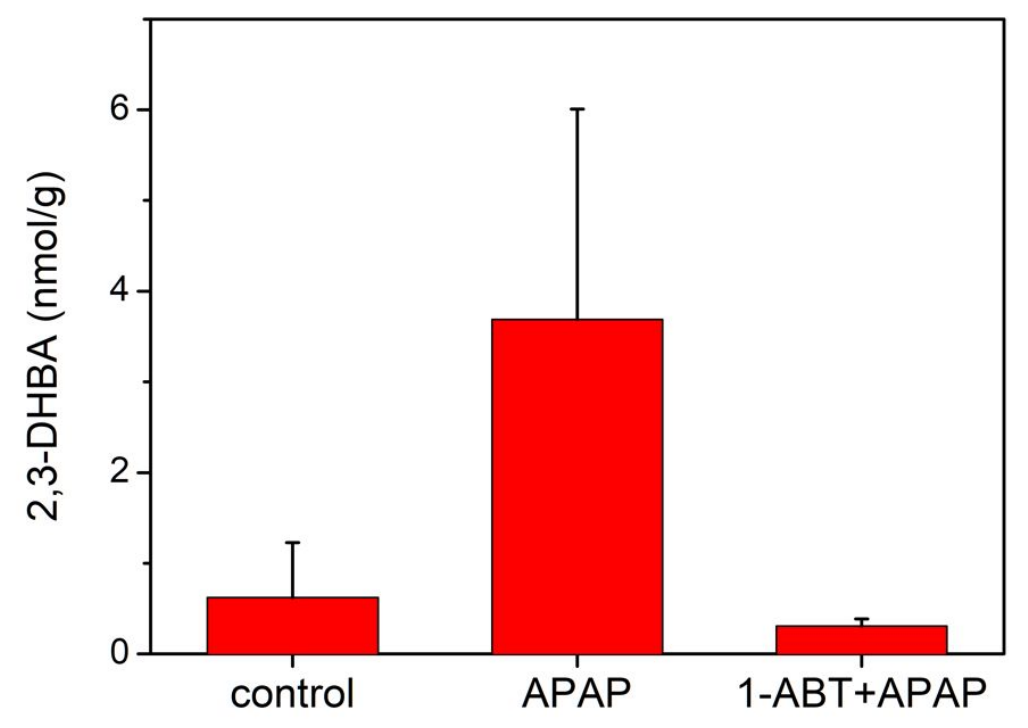


Figure S17. Quantitive analysis of 2,3-DHBA in mice liver (APAP model). Mice were intraperitoneally injected with 0 or $500 \mathrm{mg} / \mathrm{kg}$ APAP for $6 \mathrm{~h}$, then intraperitoneally injected with $100 \mathrm{mg} / \mathrm{kg}$ salicylic acid for $1 \mathrm{~h}$. Last group mice were intraperitoneally preinjected with $100 \mathrm{mg} / \mathrm{kg}$ ABT 12 and 24 hours before the injection of APAP. Then mice livers were harvested and concentrations of 2,3-DHBA were measured by LC-MS. Salicylic acid was used as a $\cdot \mathrm{OH}$ trapper; 2,3-DHBA was the specific product of salicylic acid and $\cdot \mathrm{OH}$. The concentration of 2,3-DHBA reflected $\cdot \mathrm{OH}$ level.

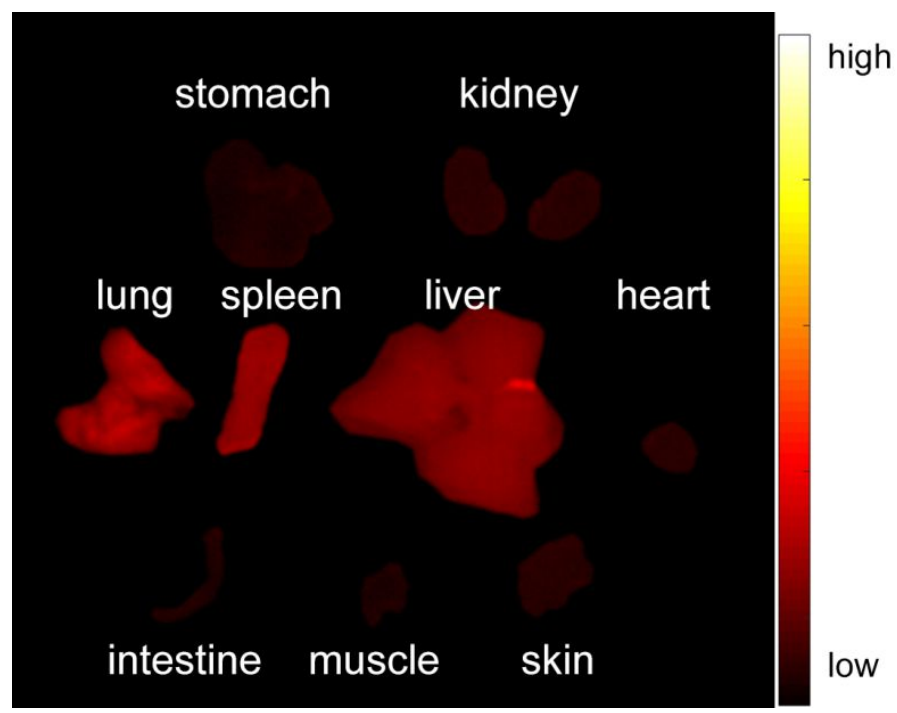

Figure S18. NIR-IIa fluorescence image of organs and tissues of Figure 6a/e group mice. 


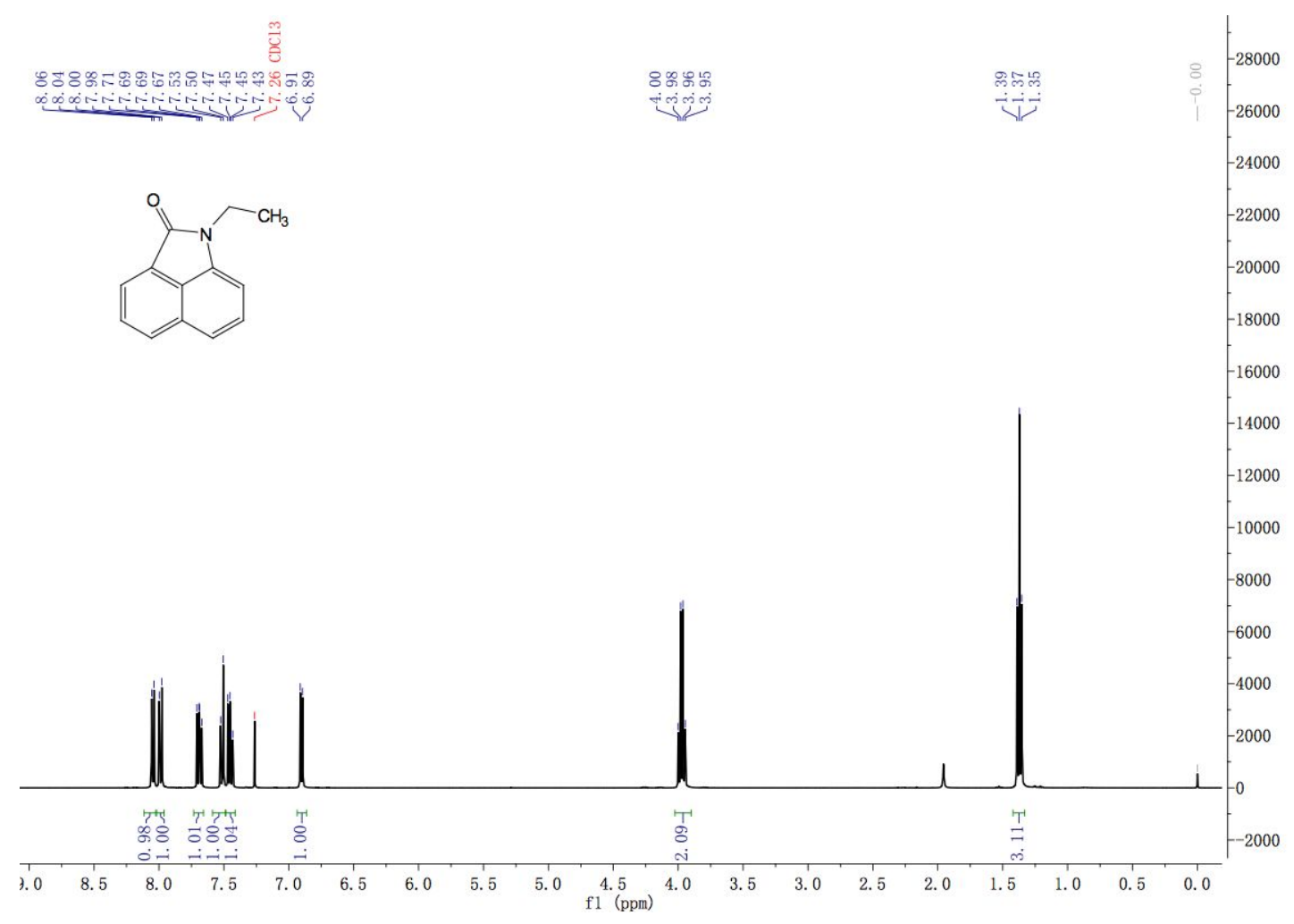

Figure S19. ${ }^{1} \mathrm{H}$ NMR spectrum of $1\left(\mathrm{CDCl}_{3}, 298 \mathrm{~K}, 400 \mathrm{MHz}\right)$.

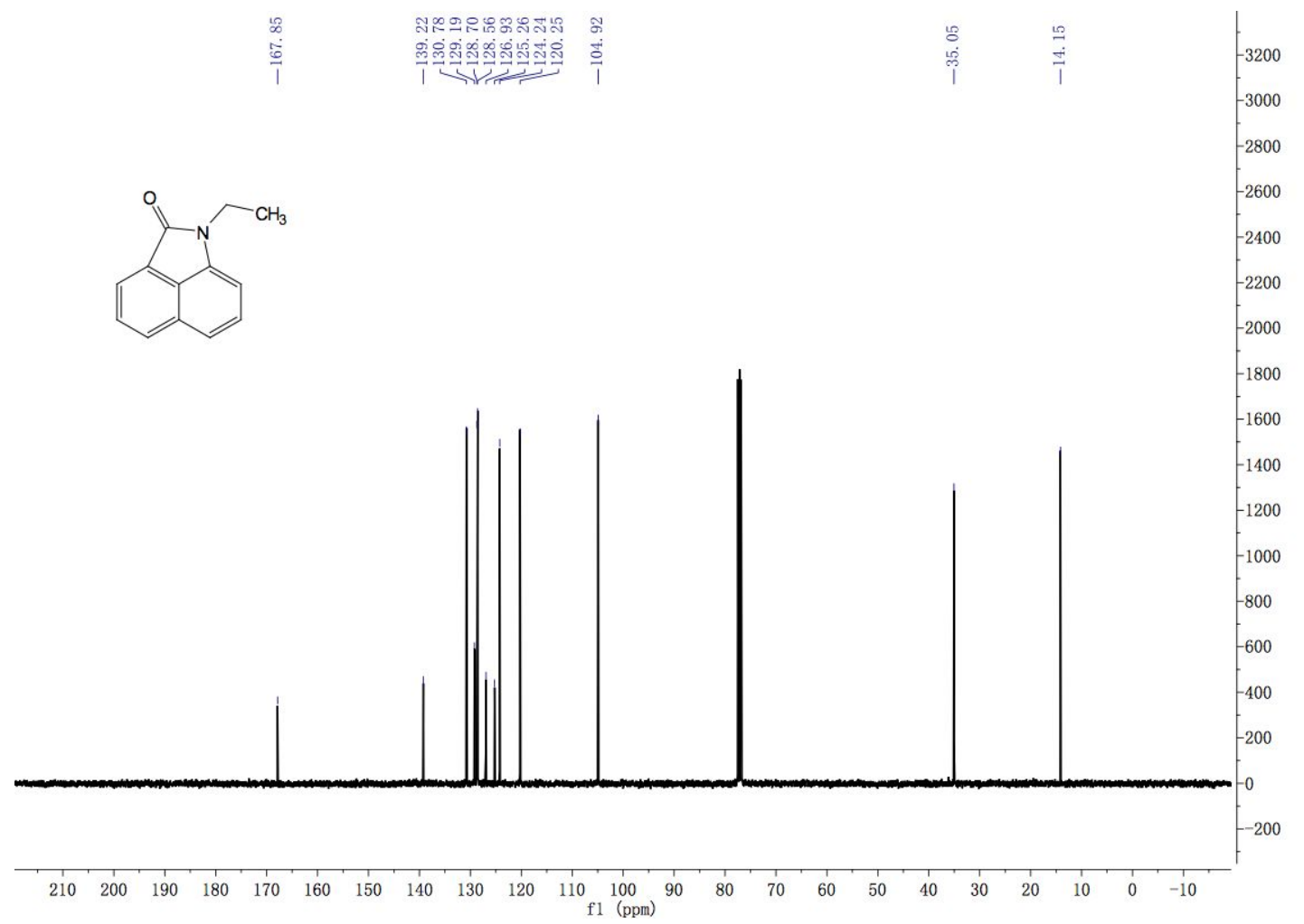

Figure S20. ${ }^{13} \mathrm{C}$ NMR spectrum of $\mathbf{1}\left(\mathrm{CDCl}_{3}, 298 \mathrm{~K}, 101 \mathrm{MHz}\right)$. 


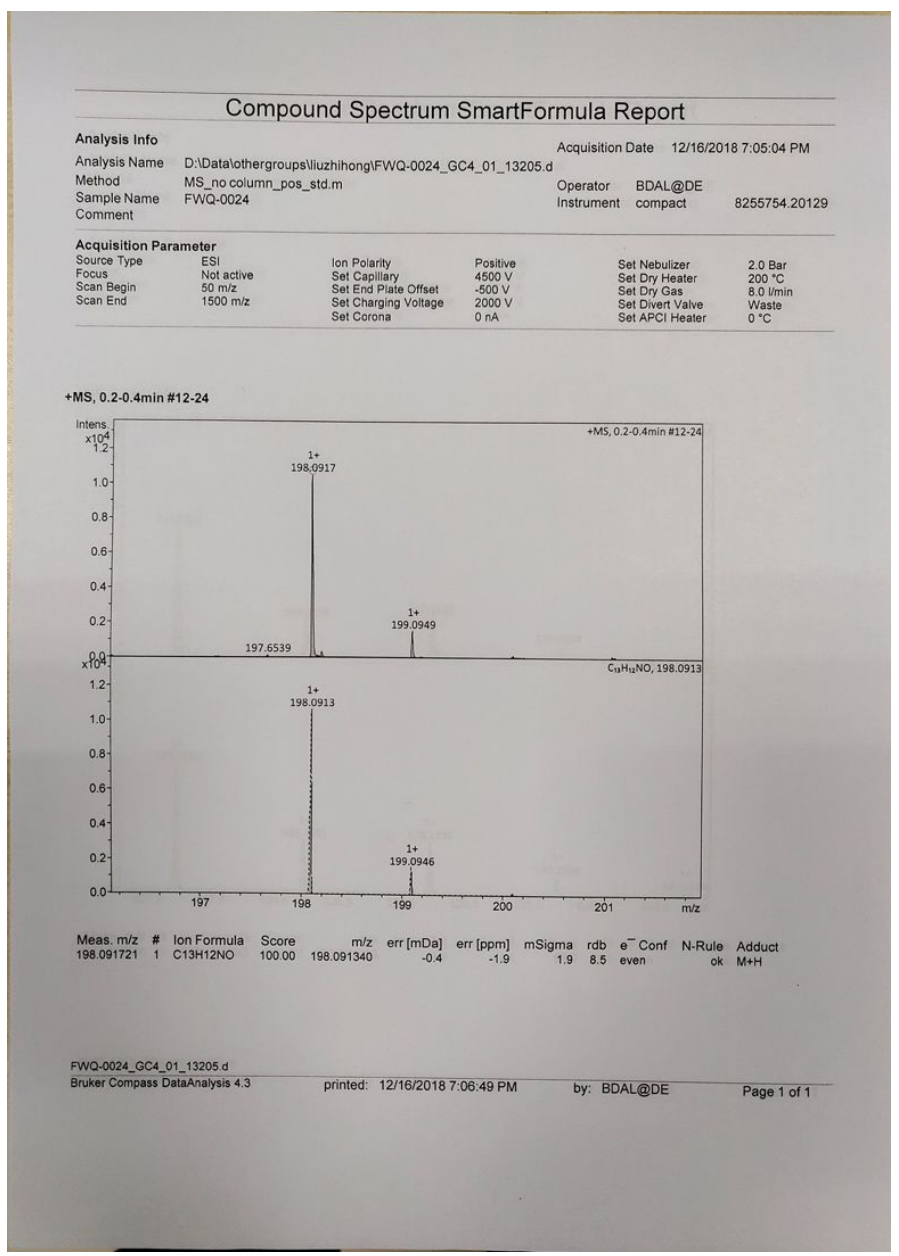

Figure S21. High resolution mass spectrum of 1. 


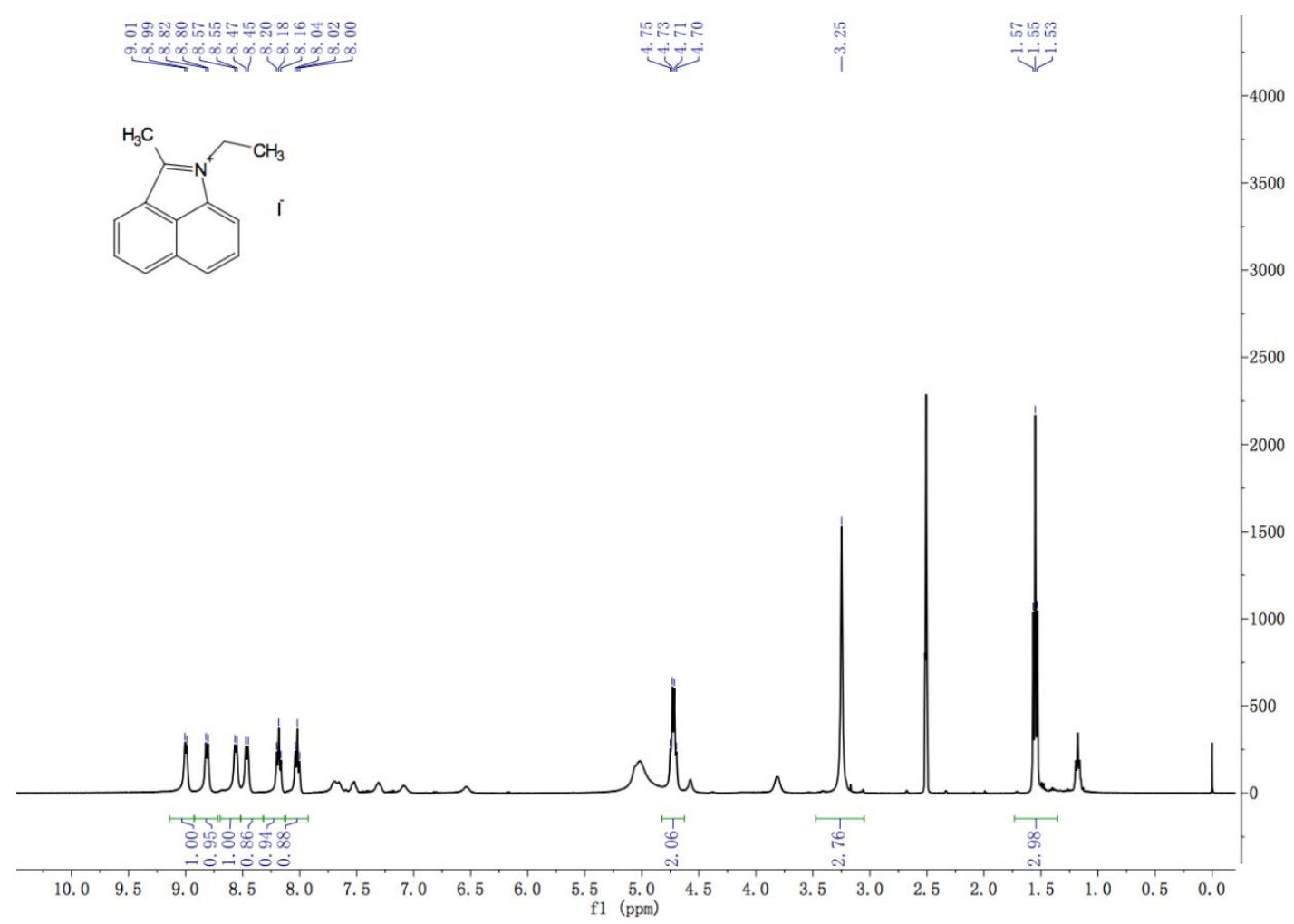

Figure S22. ${ }^{1} \mathrm{H}$ NMR spectrum of 2 (DMSO- $\left.d_{6}, 298 \mathrm{~K}, 400 \mathrm{MHz}\right)$.

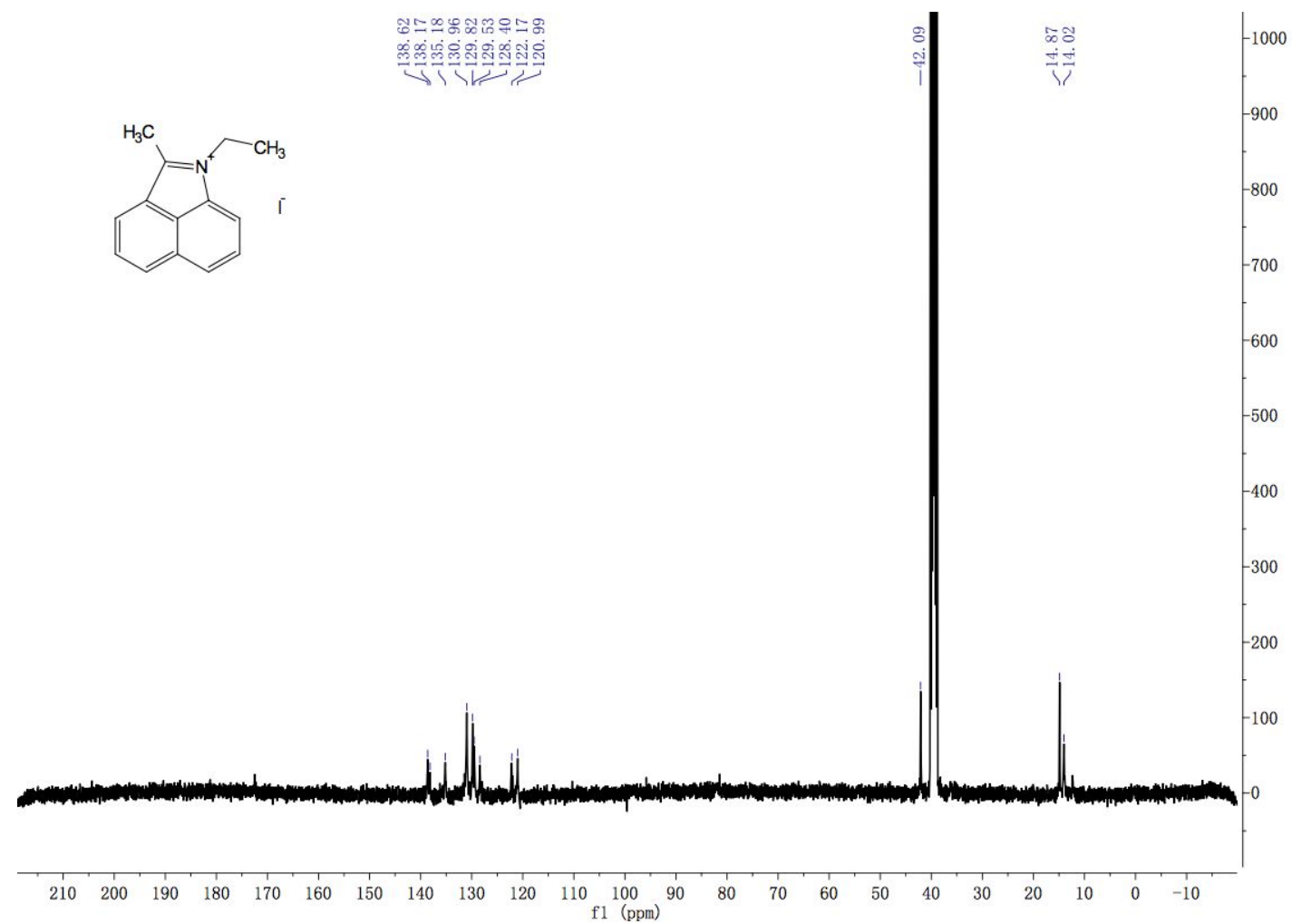

Figure S23. ${ }^{13} \mathrm{C}$ NMR spectrum of $2\left(\mathrm{DMSO}-d_{6}, 298 \mathrm{~K}, 101 \mathrm{MHz}\right)$. 


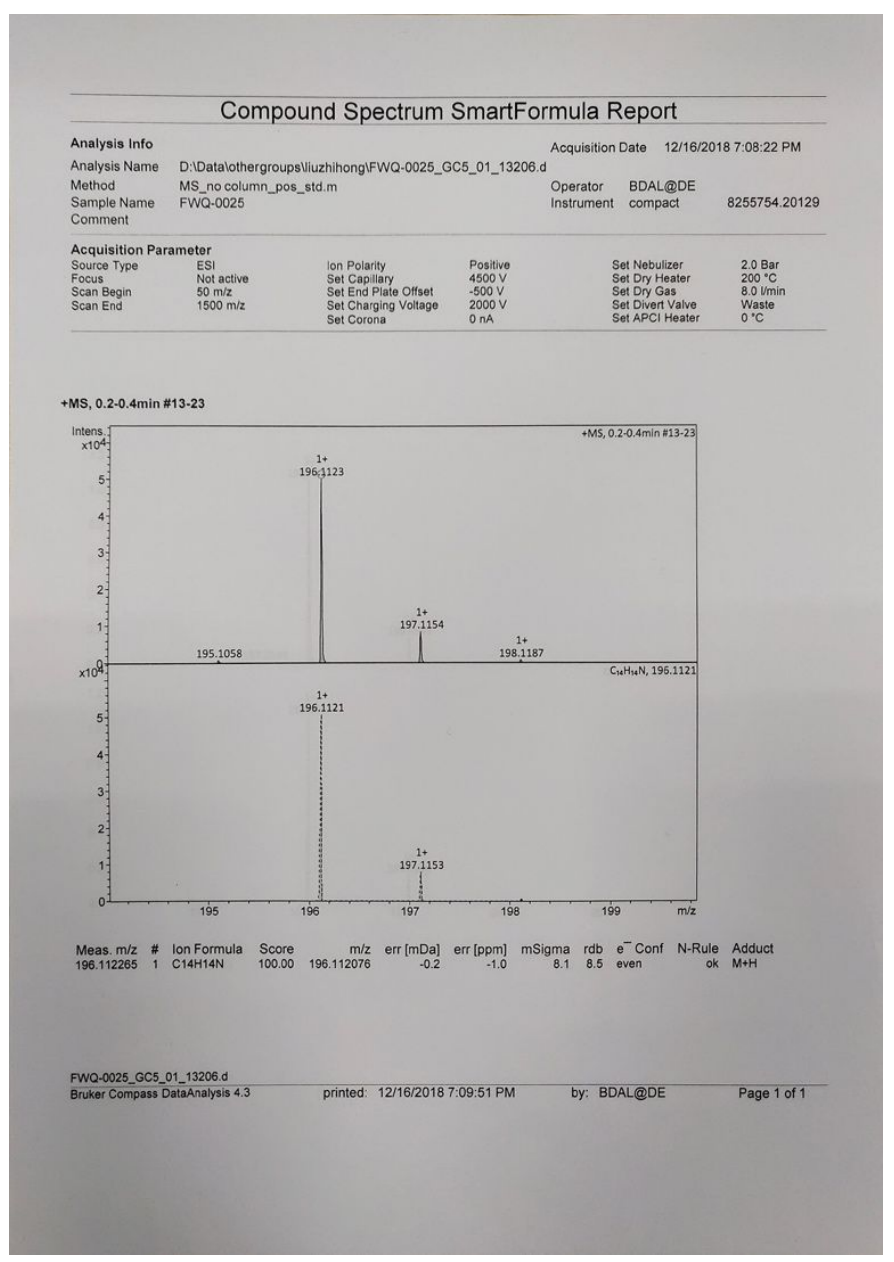

Figure S24. High resolution mass spectrum of 2. 


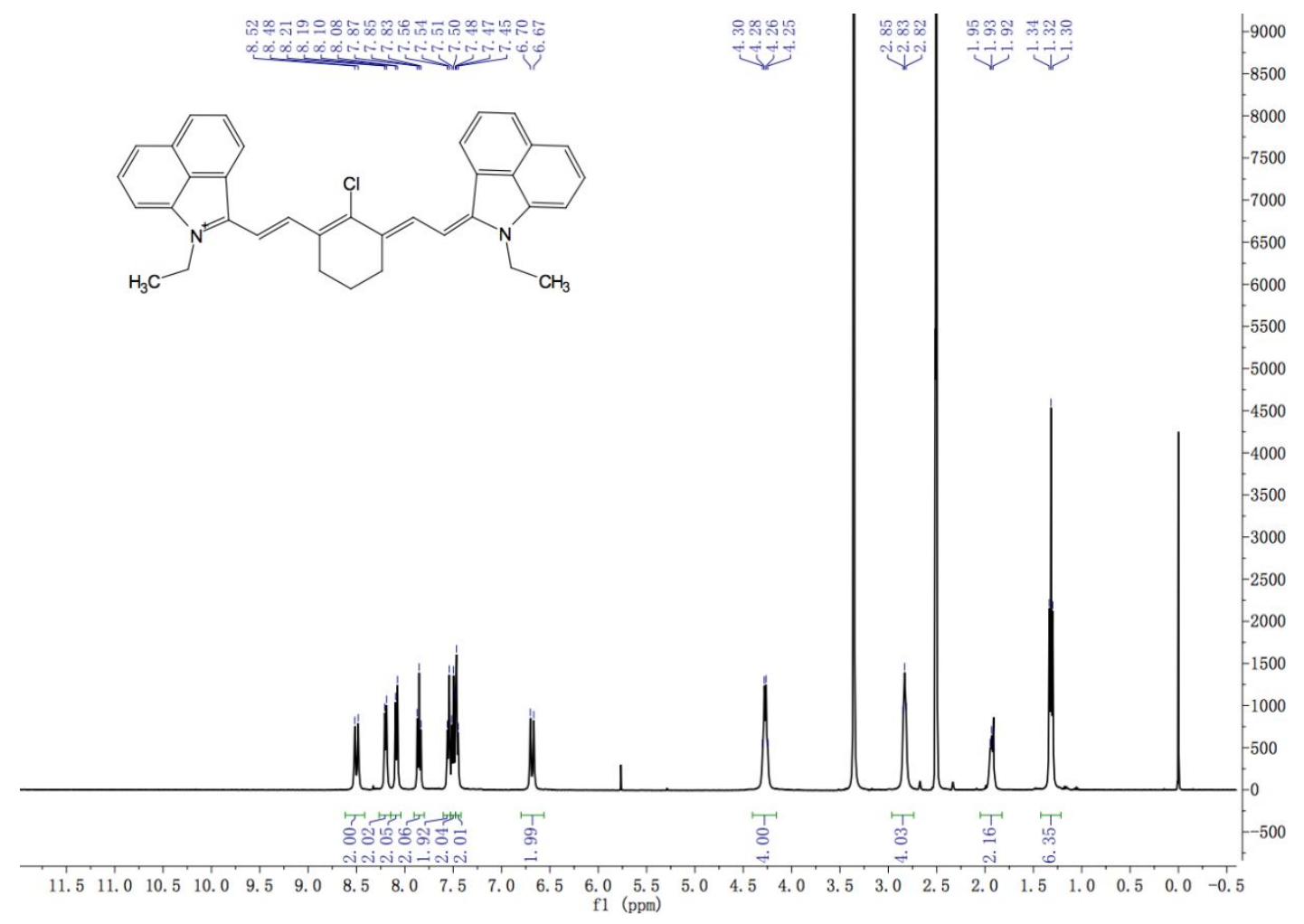

Figure S25. ${ }^{1} \mathrm{H}$ NMR spectrum of Et-1080 (DMSO- $d_{6}, 298 \mathrm{~K}, 400 \mathrm{MHz}$ ).

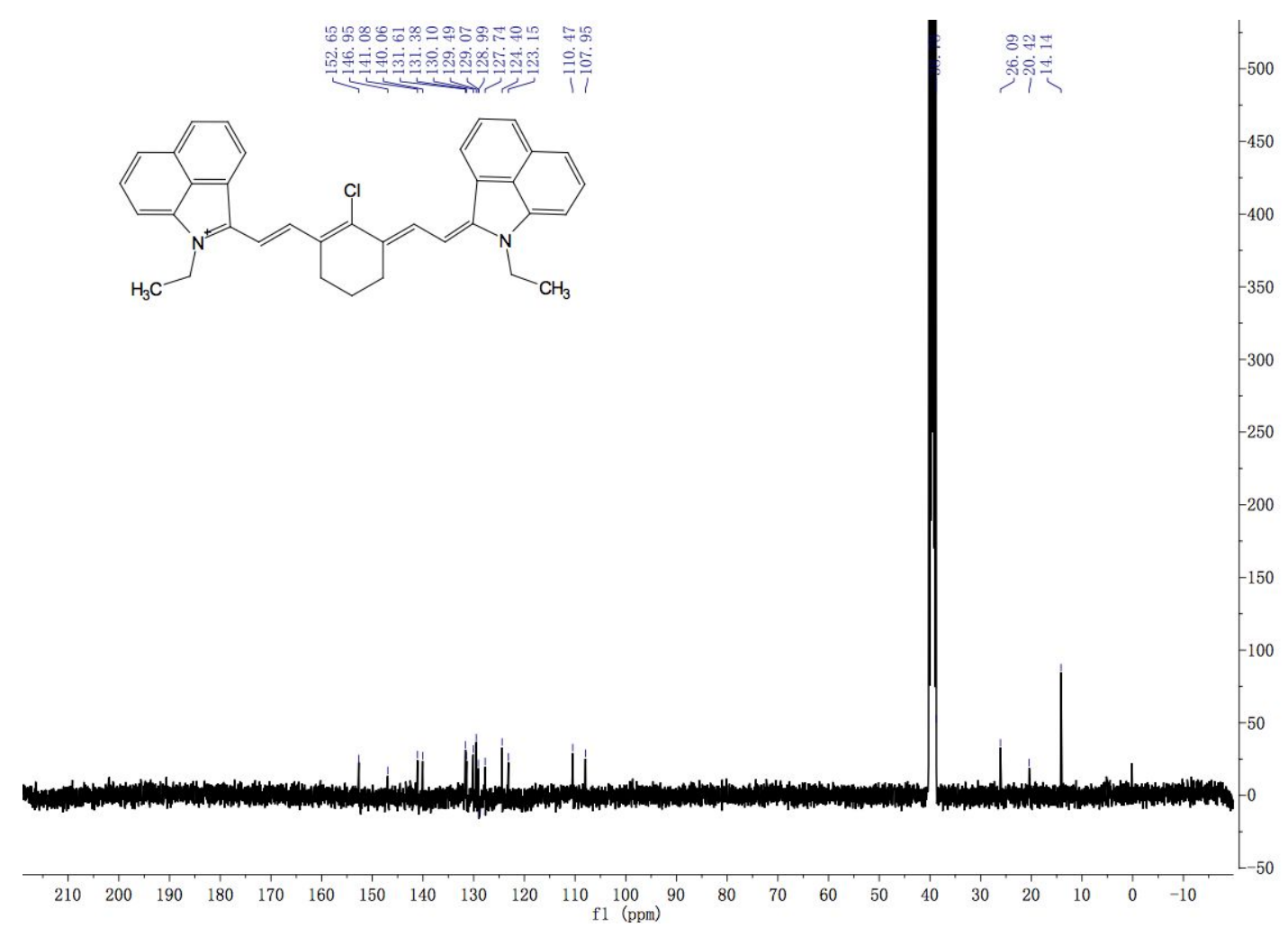

Figure S26. ${ }^{13} \mathrm{C}$ NMR spectrum of Et-1080 $\left(\mathrm{DMSO}-d_{6}, 298 \mathrm{~K}, 101 \mathrm{MHz}\right)$. 


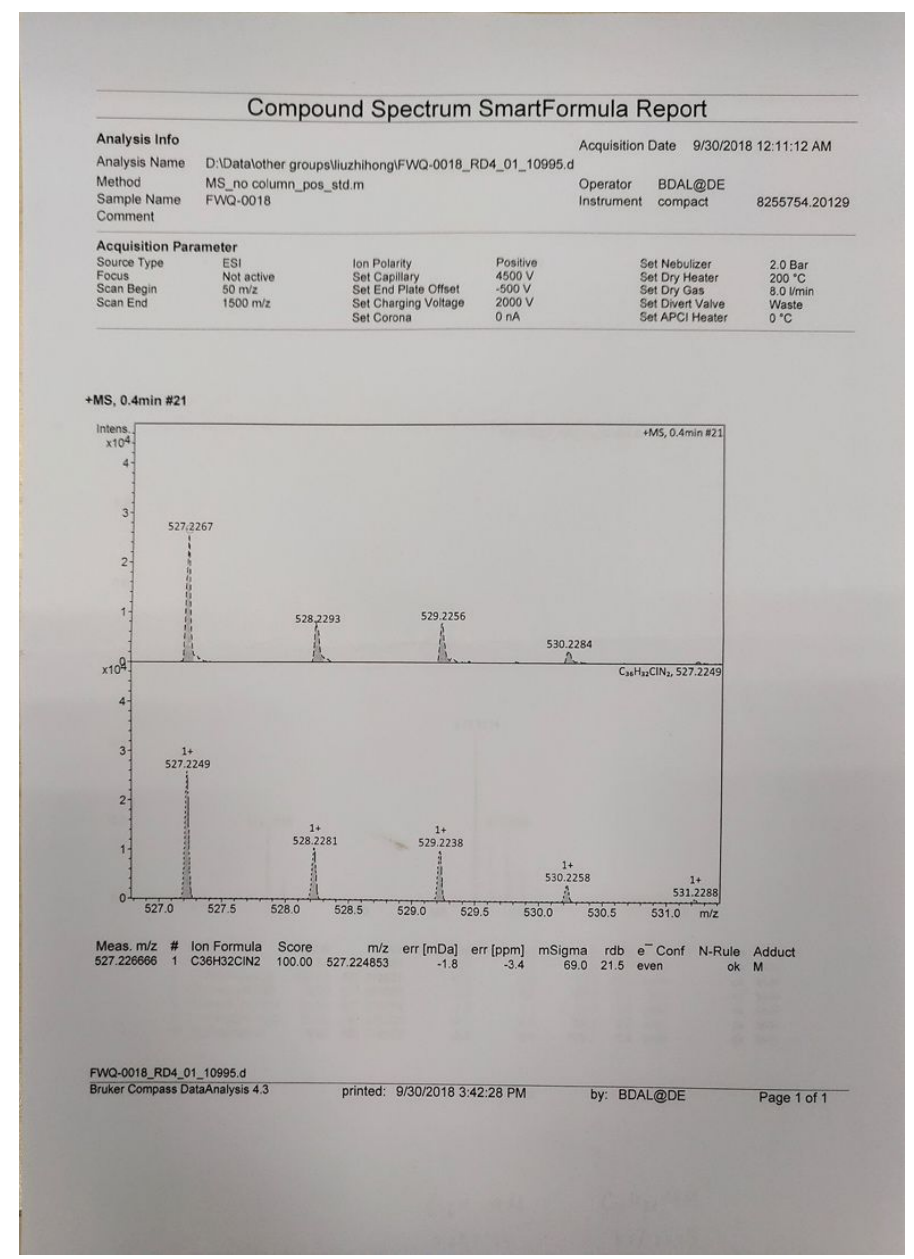

Figure S27. High resolution mass spectrum of Et-1080. 


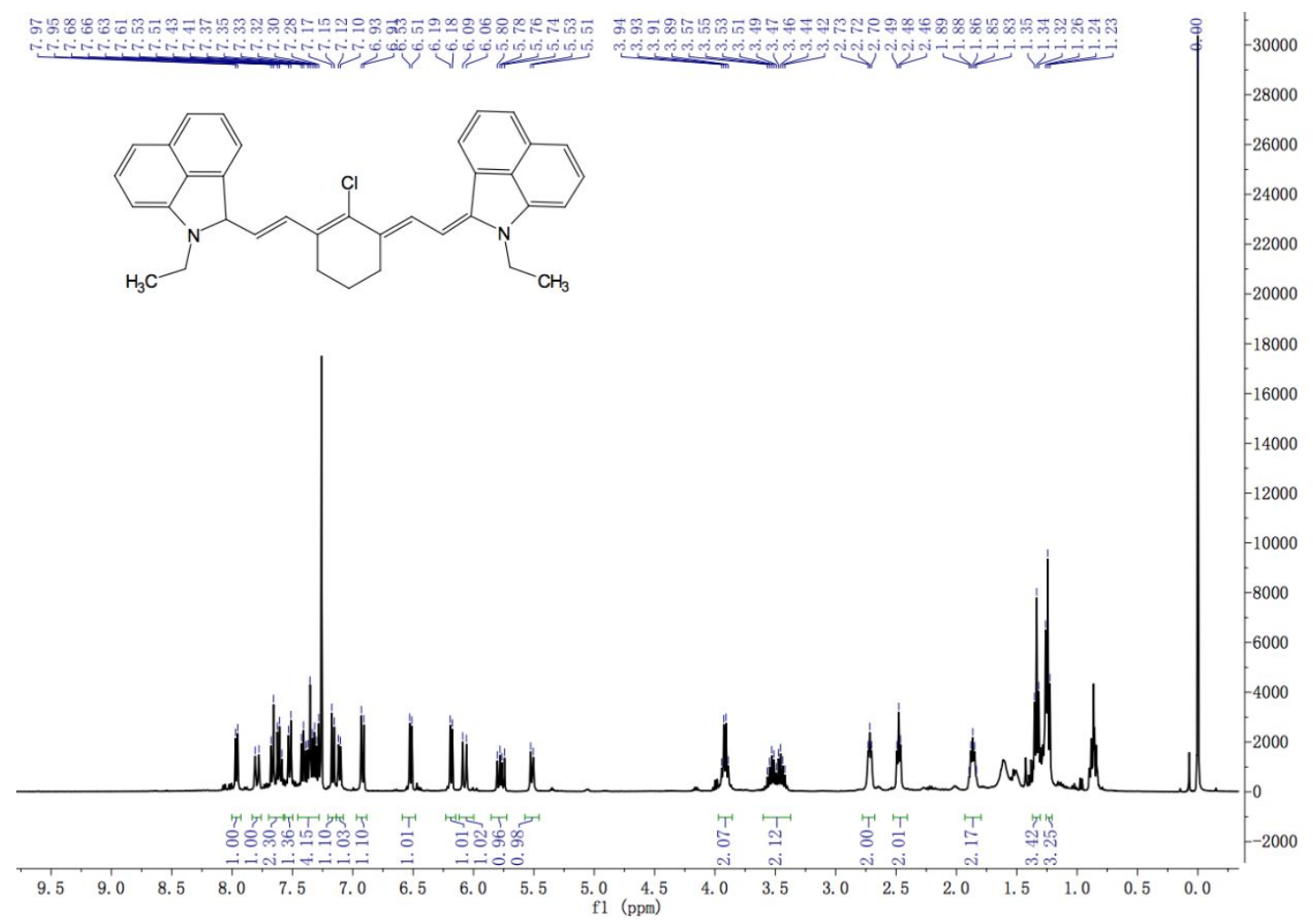

Figure S28. ${ }^{1} \mathrm{H}$ NMR spectrum of Hydro-1080 $\left(\mathrm{CDCl}_{3}, 298 \mathrm{~K}, 400 \mathrm{MHz}\right)$.

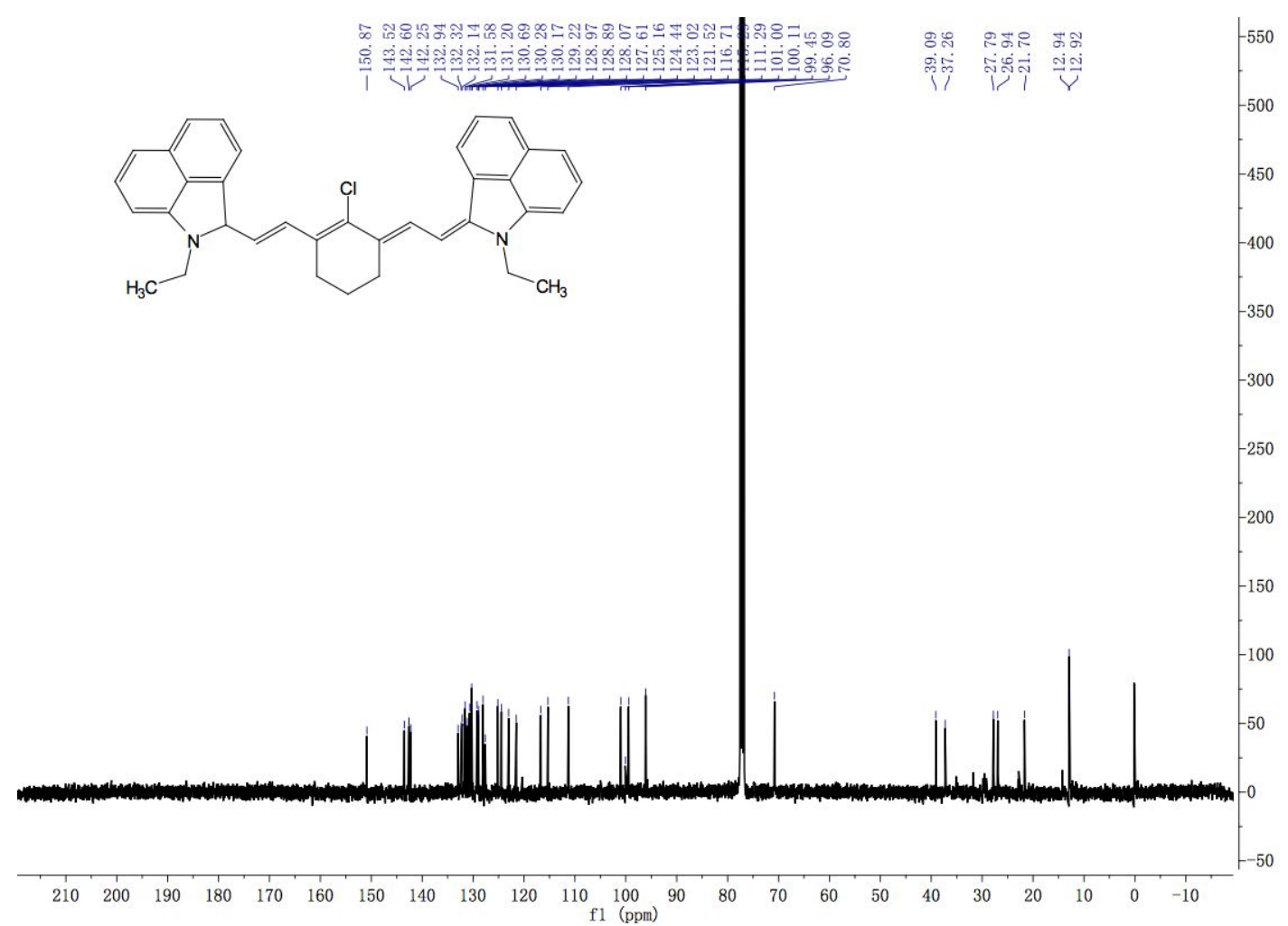

Figure S29. ${ }^{13} \mathrm{C}$ NMR spectrum of Hydro-1080 $\left(\mathrm{CDCl}_{3}, 298 \mathrm{~K}, 101 \mathrm{MHz}\right)$. 


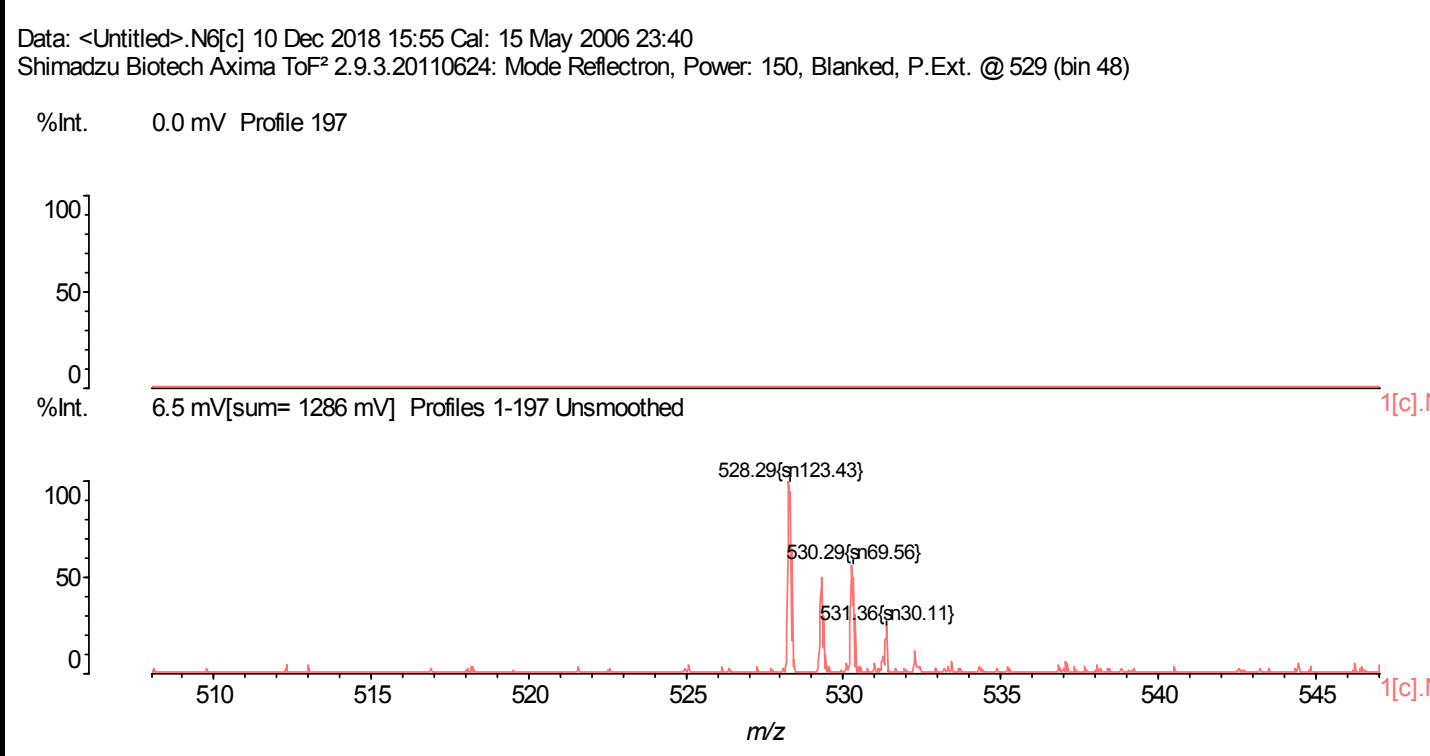

Figure S30. MALDI-TOF mass spectrum of Hydro-1080.

\section{References}

1 Li, B.; Lu, L.; Zhao, M.; Lei, Z.; Zhang, F. An Efficient 1064 nm NIR-II Excitation Fluorescent Molecular Dye for Deep-Tissue High-Resolution Dynamic Bioimaging. Angew. Chem. Int. Ed. 2018, 57, 7483-7487.

2 Cosco, E. D.; Caram, J. R.; Bruns, O. T.; Franke, D.; Day, R. A.; Farr, E. P.; Bawendi, M. G.; Sletten, E. M. Flavylium Polymethine Fluorophores for Near- and Shortwave Infrared Imaging. Angew. Chem. Int. Ed. 2017, 56, 13126-13129.

3 Casalboni, M.; De Matteis, F.; Prosposito, P.; Quatela, A.; Sarcinelli, F. Fluorescence efficiency of four infrared polymethine dyes. Chem. Phys. Lett. 2003, 373, $372-378$.

4 Frisch, M. J.; Trucks, G. W.; Schlegel, H. B.; Scuseria, G E.; Robb, M. A.; Cheeseman, J. R.; Scalmani, G.; Barone, V.; Mennucci, B.; Petersson, G. A.; Nakatsuji, H.; Caricato, M.; Li, X.; Hratchian, H. P.; Izmaylov, A. F.; Bloino, J.; Zheng, G.; Sonnenberg, J. L.; Hada, M.; Ehara, M.; Toyota, K.; Fukuda, R.; Hasegawa, J.; Ishida, M.; Nakajima, T.; Honda, Y.; Kitao, O.; Nakai, H.; Vreven, T.; Montgomery, J. A., Jr.; 
Peralta, J. E.; Ogliaro, F.; Bearpark, M. J.; Heyd, J. J.; Brothers, E. N.; Kudin, K. N.; Staroverov, V. N.; Keith, T. A.; Kobayashi, R.; Normand, J.; Raghavachari, K.; Rendell, A. P.; Burant, J. C.; Iyengar, S. S.; Tomasi, J.; Cossi, M.; Millam, J. M.; Klene, M.; Knox, J. E.; Cross, J. B.; Bakken, V.; Adamo, C.; Jaramillo, J.; Gomperts, R.; Stratmann, R. E.; Yazyev, O.; Austin, A. J.; Cammi, R.; Pomelli, C.; Ochterski, J. W.; Martin, R. L.; Morokuma, K.; Zakrzewski, V. G.; Voth, G. A.; Salvador, P.; Dannenberg, J. J.; Dapprich, S.; Daniels, A. D.; Farkas, Ö.; Foresman, J. B.; Ortiz, J. V.; Foresman, J.; Fox, D. J. Gaussian 09, RevisionD.01, Gaussian, Inc., Wallingford, CT, 2013. 